\title{
O DISCURSO TERMINOGRÁFICO NA OBRA DE MEDICINA BRASILIENSI (1648), DE GUILHERME PISO
}

\section{Lidia Almeida Barros*}

\begin{abstract}
RESUMO: Neste trabalho discutiremos a presença de um discurso lexicográfico - e mesmo terminográfico - na obra de Guilherme Piso, Da Medicina Brasileira, publicada em 1648, que consiste no primeiro tratado sobre medicina tropical do mundo. Procuraremos, assim, mostrar como esse tipo de discurso pode estar presente em documentos científicos que não se caracterizam como dicionários.
\end{abstract}

UNITERMOS: terminologia; discurso lexicográfico; discurso terminográfico; medicina; naturalistas.

RESUME: Dans cet article nous discuterons la présence d'un discours lexicographique - et même terminographique - dans l'ouvrage De Medicina Brasiliensi, publié par le holandais Guilielmus Piso en 1648, considéré comme fondateur de la Médecine Tropicale au monde. Nous essayerons donc de montrer comment ce type de discours se présente dans des documents scientifiques qui ne sont pas de dictionnaires.

MOTS-CLES: terminologie; discours lexicographique; discours terminographique; medecine; naturalistes.

\section{Introdução}

Ao procedermos a uma pesquisa específica sobre a história da Terminografia médica no Brasil, defrontamo-nos com algumas questões fundamentais à delimitação do campo de estudo e à

* Instituto de Biociências, Letras e Ciências Exatas-IBILCE, UNESP, São José do Rio Preto. 
abordagem a ser adotada. Verificamos que uma pesquisa de cunho histórico sobre os dicionários especializados (em Medicina ou em qualquer outro domínio técnico ou científico) que deseje ser abrangente não pode se ater ao conceito atual de Terminografia.

Ao estudarmos as obras brasileiras que vão do período colonial até o final do século XIX, apresentaram-se alguns elementos que consideramos preciosos para o estudo da história dos dicionários brasileiros especializados que não seriam levados em consideração caso nos ativéssemos à Terminografia stricto sensu. Nesse sentido, alargamos nosso campo de pesquisa e incorporamos ao nosso corpus documentos que, dentro de uma tipologia geral de obras, não se caracterizam de modo algum como dicionários, mas que:

1. são documentos técnicos ou científicos;

2. abordam temas de domínios especializados;

3. têm como objetivos registrar um conhecimento especializado e transmiti-lo;

4. para tanto, empregam conjuntos vocabulares que assumem o estatuto de conjuntos terminológicos, na medida em que representam e transmitem um conhecimento especializado;

5. em seu interior, dão a alguns dados um tratamento que se assemelha ao lexicográfico, ou seja, em que:

a. termos são descritos, no próprio corpo do texto, por meio de um enunciado parafrástico de tipo definicional;

b. termos são descritos em enunciados que são dispostos, no plano formal e gráfico, isoladamente uns dos outros (em forma de verbetes),

c. esses termos constituem entradas desses "verbetes";

d. as entradas são dispostas segundo certos principios de estruturação (nem sempre evidentes à primeira vista) e formam um conjunto determinado;

e. as mensagens se organizam em dois sentidos, ou seja, verticalmente (na "macroestrutura") e horizontalmente (na "microestrutura");

f. os enunciados "lexicográficos" transmitem informações de tipo lingüístico, metalingüístico ou enciclopédico. 
Nesse sentido, muitos textos científicos elaborados no período colonial brasileiro apresentam as características que acabamos de mencionar e, embora não sejam dicionários, neles encontramos um saber terminológico, no sentido de conhecimento provindo da descrição do léxico especializado empregado nesses documentos. Também ali se verifica um tratamento de tipo "dicionarístico" dos dados terminológicos, estes entendidos como "dados relativos a um conceito ou à sua designação" (ISO 1087, 1990, p. 9). Assim, consideramos que o resgate da história da Terminografia brasileira - e em nosso caso específico, da Terminografia médica no Brasil -, não pode alijar do estudo esse tipo de documento.

Cumpre ainda ressaltar que esse procedimento já foi adotado pela Lexicografia brasileira em estudos que procuram recuperar sua história. Verificamos, aliás, que boa parte do trabalho por ela desenvolvido se deu na análise de textos de cunho técnico e científico. Nesse sentido, uma parte da história da Terminologia/Terminografia brasileira já teria sido estudada pela Lexicografia.

Neste artigo nosso objetivo primeiro é o de evidenciar a presença de um discurso lexicográfico - e mesmo terminográfico -, na obra De medicina brasiliensi (1648), do holandês Guilherme Piso, e mostrar como ele se realiza. Procuraremos caracterizar o documento enquanto tipo de obra, fornecer dados biográficos sobre seu autor e obra, e contextualizá-los dentro de uma perspectiva da história das idéias científicas, tanto das Ciências Naturais, quanto da Terminologia/Terminografia. Antes dessa análise, porém, convém precisar alguns princípios teóricos nos quais nos baseamos e definir, de modo mais claro, nossa postura científica.

\section{Pressupostos teóricos}

A história da Lexicografia brasileira encontra na tese de Doutorado de José Horta Nunes (1996) uma das melhores pesquisas. Para esse autor, estudá-la "implica considerar a história do saber sobre o léxico, desde a época colonial até o momento de reivindicação de uma língua nacional distinta do português de 
Portugal" (Nunes, 1996, p. 1). Nesse sentido, propõe, com fins metodológicos, uma delimitação conceitual, a saber:

Para começar, faremos uma distinção entre o discurso de constituição do léxico e o discurso lexicográfico. $O$ primeiro inclui diversas práticas que realizam um trabalho metalingüístico envolvendo elementos lexicais (segmentação, comentários, descrições, definições), com objetivos variados, por exemplo: descrever a natureza, produzir literatura, construir conceitos científicos. O segundo se refere a um domínio específico: o da elaboração de dicionários de língua. Trataremos esta prática como um trabalho de instrumentação da língua, que se realiza em vista de determinados interesses práticos. É sobretudo este último caso que nos interessa; mas importa também mostrar de que modo o primeiro domínio incide sobre o segundo. ${ }^{1}$ (Nunes, 1996, p.4)

Numa linha de continuidade, que se inicia no discurso de constituição do léxico e chega ao discurso lexicográfico no Brasil, estabelece-se o que o autor chamou de saber lexicográfico:

O saber lexicográfico de que trataremos aqui é aquele que se inicia no Brasil com os primeiros escritos sobre o país. Nesse sentido, ele surge juntamente com a etnografia (conhecimento dos povos indigenas), a economia (mercantilismo) e a geopolítica (expansão territorial das nações européias), em seus momentos precursores, introduzido através de relatos de viajantes, colonos e missionários. Tais textos estão pontuados por citações de termos indigenas, de modo que é formulada uma constelação de comentários lexicais. (Nunes, 1996, p. 11)

Assim, as cartas, os relatos de viajantes, narrativas oficiais, estudos científicos (Tratados) produzidos no período colo-

1 Todos os destaques (negritos) das citações mencionadas neste trabalho são nossos. 
nial, que descreviam o Brasil em seus diferentes aspectos, em muito contribuíram para a elucidação de conjuntos léxicos indígenas e para o enriquecimento do português do Brasil, sobretudo no que concerne a unidades lexicais que designavam coisas exóticas, próprias do local ou nele existentes, desconhecidas dos colonizadores ou de cientistas estrangeiros. Ao falar sobre as coisas, e ao descrevê-las nos documentos, produzia-se um discurso de tipo lexicográfico. Essa é, aliás, uma característica marcante dos documentos elaborados então, o que contribuiu para a construção de um saber sobre as coisas, as designações e os conceitos. Sobre essa questão, Nunes diz:

Os comentários dos viajantes se direcionam para as coisas do Novo Mundo, de maneira que a questão da referência torna-se importante nesse contexto. Ao descrever as novidades do país, esses falantes colocam em evidência os referentes. Fala-se de lugares, animais, plantas nunca vistos (embora já nomeados pelos autóctones); fala-se de coisas não-idênticas, mas semelhantes; constata-se a existência ou inexistência de coisas. Nessas circunstâncias, a organização dos espaços lexicais está intimamente relacionada com a geografia e a economia, com os interesses de conquista e de comércio. Esse estado do saber lexicográfico envolve uma variada tipologia discursiva, em que se incluem narrações, descrições, traduções e diálogos. Temos em vista, sobretudo, os deslocamentos que ocorrem quando se passa de uma configuração dispersa, pontual, dos comentários lexicais inseridos nesses diferentes tipos de discurso, a uma configuração localizada, que já se pode observar nos próprios viajantes, com a elaboração de listas de palavras com comentários ou explicações. (Nunes, 1996, p. 12)

Nesse sentido, o saber lexicográfico que marcou o período colonial brasileiro construiu-se (ou se manifestou), em parte, por documentos que procediam a descrições das coisas da terra e do léxico que as designava, sem, entretanto, terem um caráter puramente lexicográfico. Assim, descreviam as palavras no pró- 
prio texto, utilizando, para tanto, um enunciado de tipo definicional; por vezes anexavam listas temáticas, que geralmente compreendiam termos em linguas indigenas com os respectivos equivalentes em português; ou, ainda, organizavam as informações sobre determinado termo de forma muito parecida com a de verbetes dos dicionários.

Telmo Verdelho também observa a presença de uma lexicografia implicita em documentos portugueses antigos que não se caracterizavam como dicionários:

A emergência da escrita entre os vernáculos europeus, desde a recuada Idade Média, paralelamente à escolarização do latim, deu naturalmente origem à dicionarização das línguas vulgares. Gerou-se em primeiro lugar uma espécie de lexicografia implícita que tecia os próprios textos e facilitava a compreensão do vocabulário característico da escrita, forçosamente mais amplo e menos quotidiano do que o da língua oral. Os textos que dão testemunho das primeiras tentativas do uso da escrita em vernáculo português e ainda quase toda a produção textual subseqüente, até aos tempos modernos, vêm marcados por esse esforço metalingüistico de clarificação e autodescodificação, próximo da informação lexicográfica. Muitos textos medievais portugueses parecem ser construídos com a preocupação de fornecerem um fácil acesso à significação do seu próprio léxico, apresentando um estilo parafrástico, enquadrado por muitas palavras redundantes e freqüentemente entretecido por verdadeiras definições lexicográficas. Os exemplos mais elucidativos poderão recolher-se nos textos jurídicos de Afonso $\mathrm{X}$, tais como as Partidas e o Foro Real traduzidos do castelhano logo nos primeiros séculos da escrita em língua portuguesa. (Ferreira 1980 e 1987). Os textos da Casa de Avis, e muito especialmente o Leal Conselheiro de D. Duarte, oferecem também bons exemplos de fundo prédicionaristico que acompanhou o início da memória textual portuguesa. $O$ Leal Conselheiro apresenta-se mesmo como obra de tipo paralexicográfico nas declara- 
ções do próprio autor (" $E$ fillayo por hûu A B C de lealdade"). (Verdelho, 2002, p. 16)

Verifica-se, portanto, que, em Portugal e no Brasil, um saber lexicográfico ou uma lexicografia implícita marca diversos documentos antigos, embora por motivos e em situações diferentes, como não poderia deixar de ser, uma vez que "o saber lingüístico é um produto histórico, localizado em um tempo e em um espaço" (Nunes, 2002, p. 100).

No âmbito deste trabalho, apoiamo-nos nos conceitos propostos por Nunes e Verdelho, porém com algumas adaptações: não distinguiremos discurso de constituição do léxico de discurso lexicográfico, ao contrário, preferimos empregar este último em sentido mais abrangente. Ou seja, o termo discurso lexicográfico assumirá, neste artigo, o sentido dado por Nunes a discurso de constituição do léxico, e dado por Verdelho a lexicografia implícita ou a texto paralexicográfico. Nossa postura teórica procura se adaptar ao nosso objeto de estudo, visto que, diferentemente de Nunes e Verdelho - que estudaram também obras de caráter eminentemente lexicográfico -, ater-nos-emos à análise de apenas um documento no qual se evidenciam elementos de tipo lexicográfico, mas que não tinha, quando de sua redação, nenhuma intenção de se caracterizar como dicionário.

Ao falarmos de "tratamento dicionarístico" aplicado a dados terminológicos, automaticamente somos induzidos a pensar em saber terminográfico. Convém, porém, a nosso ver, não empregar de modo generalizado essa expressão, uma vez que, se por um lado é verdade que em alguns documentos se evidencia um tratamento que em certos aspectos lembra a metodologia empregada pela Terminografia moderna, por outro, alguns documentos não permitem essa observação.

Com efeito, por Terminografia a Norma ISO 1087 compreende "o registro, tratamento e apresentação de dados terminológicos obtidos por uma pesquisa terminológica" (ISO 1087, 1990, p. 13 ). A Terminografia constitui, juntamente com a análise terminológica (entendida como o "estudo sistemático dos conceitos e dos termos de acordo com os principios e métodos da ciência da Terminologia" (Idem, ibidem)), o trabalho terminológico, defi- 
nido como uma "atividade relativa à sistematização e à representação dos conceitos, assim como da apresentação de terminologias de acordo com os principios e métodos estabelecidos" (Idem, ibidem). Assim, se nos ativermos a esses conceitos, a pesquisa deve se restringir aos dicionários especializados cuja elaboração se baseia em princípios teóricos e metodológicos próprios da Terminologia moderna e da Terminografia como concebida acima.

Nesse sentido, acreditamos ser mais prudente falar de modo genérico de saber lexicográfico ou ainda de discurso lexicográfico, reservando o emprego de saber terminográfico ou discurso terminográfico às manifestações discursivas que resultam de um tratamento dos dados que se assemelha, de alguma maneira, ao adotado pela Terminografia atual.

\section{O autor e sua obra no contexto histórico}

Guilherme Piso é a forma portuguesa, que provém da latinizada Guilielmus Piso, do nome do naturalista Willem Pies, membro da missão científica enviada pela Holanda ao Brasil no período em que vasta região, que vai de Pernambuco ao Rio Grande do Norte, ficou sob o domínio holandês e sob o governo do Príncipe Maurício de Nassau (entre 1630 e 1654). Este, antes de viajar para o Brasil, solicitou à Companhia das Índias Ocidentais que se organizasse uma missão com fins científicos. É evidente que a exploração comercial de uma colônia não poderia ser levada a cabo sem o conhecimento dos recursos naturais de que essa dispunha. Nesse sentido, a expedição também obedecia a um propósito imperialista. Ela não ficou, porém, para a História como uma missão de tal cunho: essa empreitada científica cobriu-se do mais alto valor para o estudo da natureza brasileira e legou à Ciência um dos documentos de maior qualidade na matéria.

Nascido em 1611, em Leyden, Holanda, Guilherme Piso assumiu, aos 26 ou 27 anos, a função de médico particular de Maurício de Nassau e de chefe da expedição científica enviada ao Brasil pelo governo batavo. Foram ainda nomeados para a missão os alemães Georg Marcgrav (médico) e Henrique Cralitz 
(astrônomo). Durante sua estada no Brasil, esses cientistas procederam a estudos médicos, naturalistas, astronômicos, antropológicos e sociológicos. Suas anotações deram origem à magistral obra Historia Naturalis Brasiliae, à qual nos ateremos mais amiúde adiante.

As pesquisas desenvolvidas por Piso no Brasil encontraram em Marcgrav um grande companheiro. Com este dividiu a honrosa e dificil tarefa de estudar o Brasil da época. Ao que tudo indica, Piso se interessava mais pelos aspectos médicos e Marcgrav dedicou-se à análise de questões relacionadas à História Natural propriamente dita. Essa divisão não foi, entretanto, rígida, tendo Marcgrav também feito observações médicas, sobretudo quando da descrição de espécies da flora brasileira e de animais. Por sua vez, em sua obra De medicina brasiliensi, Piso dedicou capítulos inteiros aos animais venenosos e às propriedades medicinais das plantas brasileiras.

No que concerne às referências científicas de Piso, este estudou o que de melhor havia na Medicina da época e em periodos anteriores:

As grandes autoridades por Piso mais frequentemente invocadas são, e não poderiam deixar de sê-lo, entre gregos e romanos, Hipócrates, Galeno, Dioscórides, Paulo de Egina ou Egineta, Aristóteles, Plínio, Celso, Aetius, o autor e compilador do Tetrabiblos, os famosos arabes Serapião e Avicena, dentre os tratadistas de maior e menor antiguidade. Dos mais próximos de seu tempo cita sobretudo a Mattioli, o famoso comentador italiano de Dioscórides e arquiatra do Imperador Maximiliano II (1500-1577); Rembert Doodens, belga, muito mais conhecido pelo nome latinizado de Dodonaeus (1518-1585), também médico do mesmo soberano alemão; Jacob Bontius, o afamado autor da Medicina das Indias, falecido em Batávia no ano de 1631 (e cujas obras foram aliás publicadas pelo próprio Piso); Gaspar Hofmann (1572-1648), o sábio professor de Altdorf, cujos tratados desfrutavam então reputação européia; Próspero Alpini ou Alpinus, o sábio botânico italiano cujo nome inapagàvelmente se prende à história do 
café (1553-1617). Leu Piso, com atenção, o nosso Garcia Orta, ou Ab Horto, como lhe chamavam cientificamente, o amigo de Gamões e médico de Martim Afonso de Sousa, o autor encantador do Colóquio dos simples, que de L'Ecluse (Clusius) traduziu e o Conde de Ficalho tão eruditamente comentou. Mas não são só êstes célebres botânicos os que Piso citou: fala-nos de outros entre os quais nos lembramos de Vorstio. De todos aquêles em que se apoiou, o mais célebre é certamente Clusius, nome latinizado de Charles de l'Ecluse (1526-1609), primeiro francês que escreveu sôbre o café. (Taunay, 1948, p. 228)

Estudou ainda Botânica nas obras de Nicolau Monardes (de Sevilha), de Doodens e de Vortius (ou Adolfo Vorst,15971663); Patologia nas dos médicos Rodrigues Guerrero (espanhol) e Felix Plater (suiço, 1536-1614), Senertus (Daniel Sennert, célebre médico alemão, 1573-1637); Fernelius (João Fernel, 14971558), Solenander (Regnerius, alemão, 1525-1604); e Medicina Legal nas obras de Paulo Zaquias.

Ao conhecimento acumulado pelos estudos feitos nas Academias européias de renome na época, somaram-se a pesquisa de campo e as experiências práticas em terras brasis. Essa combinação de elementos conduziu-o a alargar os quadros da Patologia da época e a desenvolver terapêutica eficaz para inúmeros males, o que lhe angariou o título de fundador da Nosologia ${ }^{2}$ brasileira e da Medicina Tropical no mundo. Em sua obra biográfica intitulada Marcgrave e Piso (1918), Juliano Moreira aprecia o trabalho desses autores e, no que concerne a Piso, afirma (apud Taunay, 1948, p. 214):

Esta obra, evidentemente magistral, reexaminada com afinco, evidencia, a cada perquisição, excelências novas, e, por isso, ainda é hoje, uma das mais lídimas glórias da literatura médica holandesa. A Piso devemos uma descrição, exata e minudente, das endemias então reinantes no

2 Parte da Medicina que estuda as doenças em geral e procede à sua classificação analítica. 
Brasil e dos meios de tratá-las. Observou a bouba, o tétano, paralisias várias, a disenteria, a hemeralopatia, o maculo. Descreveu a ipeca e sua qualidade emeto-catártica, das quais já se utilizavam os aborígenes muito antes do célebre médico Adriano Helvetius, avô do notável filósofo francês Cláudio Adriano Helvetius, haver recebido de Luís XIV mil luíses de ouro, títulos e honrarias, por haver descoberto exatamente aquelas mesmas virtudes terapêuticas. De 1688 data o Tratado de Helvetius intitulado Remède contre le cours du ventre.

Mostrou a ação terapêutica do coco andaaçú, do tipi, do sassafrás, da japecanga, da capeba ou pariparoba, do jaborandi. A propósito deste último vegetal, Pies, em vários lugares de sua obra, faz menção muito nítida de suas propriedades sialagogas e diaforéticas, sendo admirável, como dizem os médicos holandeses Bauer e Stokvis, tenha a medicina levado tantos anos para descobrir esses fatos.

A essas contribuições somaram-se tantas outras, como a do desenvolvimento de socorro mais eficaz contra picadas de cobras e outros animais venenosos do que os (já então revolucionários) tratamentos dados pelos indígenas brasileiros.

Nunca escondeu que em muito se enriqueceu com os conhecimentos dos povos indígenas sobre a natureza, ao contrário, em inúmeras oportunidades fez-lhes rasgados elogios, atribuindo-lhes grande sabedoria e, em atitude humilde digna de um verdadeiro cientista, reconheceu-lhes méritos, dando uma contribuição para que os acadêmicos seus contemporâneos vissem com outros olhos o silvícola brasileiro. Criticou a Medicina da época por não estudar questões de grande importância, como antídotos a venenos, soros antiofídicos e doenças que atacavam de modo particular mulheres e crianças. Seu espírito investigador se contrapunha à postura de muitos cientistas antepassados e contemporâneos de Piso, que predicavam que nada mais havia a estudar sobre a Natureza, segundo eles, já totalmente descrita.

Com esse espírito, o médico batavo lançou-se no estudo de campos nunca dantes explorados cientificamente, deixando 
grande legado à Medicina. Não apenas as ciências médicas e naturais lhe devem algo, mas a Astronomia e a Geografia também. De fato, graças ao observatório astronômico construído por Maurício de Nassau, Piso pôde fazer observações importantes sobre distâncias entre a Europa e o Novo Mundo. Afirmava ter encontrado graves erros em cartas geográficas da época, que davam posição mais próxima ao Brasil em relação ao Velho Continente do que a real distância.

Tanto seu trabalho, quanto o de Marcgrav destacam-se por exporem os dados sob uma nova ótica:

Enquanto os primeiros viajantes e colonos, ao descreverem a natureza, introduzem aspectos socioeconômicos, aqueles de uma economia externa, estes de uma economia interna, com Marcgrav [ de Piso também] a natureza se despe das finalidades mercantilistas e culturais. O dominio das ciências naturais começa a restringir suas fronteiras, excluindo do espaço da fauna e da flora os comentários sobre o homem, os costumes e o comércio. (Nunes, 1996, p. 71-72)

Os naturalistas descrevem, portanto, o Brasil sob uma perspectiva diferente da até então adotada pelos relatos e estudos empíricos ou científicos. 


\section{A Historia Naturalis Brasiliae}

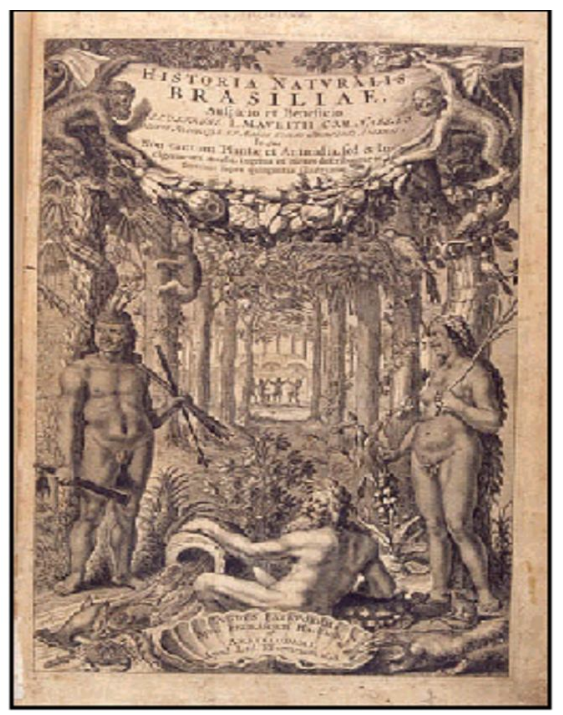

Guilherme Piso (1611-1678) e Georg Marcgrav (1610-1644) são os autores principais da obra magistral Historia naturalis brasiliae, publicada em 1648 em Leyden (Holanda), na casa de Francisco Háckio, e em Amsterdam, na de Lud. Elzevir. Em 1948, a Imprensa Oficial do Estado de São Paulo, comemorando o cinqüentenário de sua fundação, publicou (Edição do Museu Paulista) a tradução do Dr. Alexandre Correia, com estudo biográfico dos autores e prefácio de Afonso de Escragnolle Taunay (1876-1958). É com base nessa edição que procederemos ao nosso estudo. Cumpre ressaltar que citaremos o texto em português, mas a obra foi originalmente escrita em latim. Limitaremos nossa análise aos livros de Piso, embora a Historia naturalis brasiliae não seja composta apenas de seu trabalho. De fato, essa obra compõe-se dos seguintes documentos:

1. DE MEDICINA BRASILIENSI, de autoria de Piso, composta de quatro livros dedicados a questões médicas: I. Dos ares, das águas e dos lugares (do Brasil); II. Das doenças endêmicas; III. Dos venenos e antídotos; IV. Das faculdades dos símplices.

2. HISTORIAE RERUM NATURALIUM BRASILIAE, de autoria de Marcgrav, composta de oito livros: três dedicados ao estudo 
das plantas, um aos peixes, um às aves, um aos quadrúpedes e serpentes, e um à região e seus habitantes.

3. Do APPENDICE DE TAPUYIS, ET CHILENSIBUS, de João de Laet.

A Historia Naturalis Brasiliae tem, portanto, dois autores principais e um grande co-autor (João de Laet). A participação de Marcgrav é, como podemos observar, especial, uma vez que dos doze livros, oito são de sua autoria. Este é, aliás, considerado por muitos como o autor principal. A publicação da obra é póstuma no que concerne a esse cientista, já que faleceu em Angola, em 1644, com apenas 34 anos.

\section{De medicina brasiliensi}

\subsection{Estrutura e conteúdo}

Nos quatro livros de autoria de Piso, este procede ao mais completo estudo científico sobre as doenças, remédios, propriedades medicinais de plantas, venenos e antídotos, características do ar e das águas do Brasil do século XVII, só tendo sido superado muitos anos mais tarde e, em alguns aspectos, nunca superado.

Além dos elementos estudados, conta a perspectiva da descrição, ou seja, a visão de um naturalista, com a formação de Piso, sobre questões médicas do Novo Mundo. Assim, o que antes era visto como apenas um alimento passou a ser considerado como algo importante para a cura de certos males; o que antes era crendice foi comprovado ou descartado pela análise científica; o que antes era desprezado, passou a ser objeto de atenção; enfim, o que antes era charlatanice (dos curandeiros indigenas ou portugueses) ganhou o respeito de um verdadeiro cientista.

Dentre as inúmeras inovações no campo dos estudos médicos feitos no Brasil colonial, apresentadas por Piso em sua obra, encontram-se as observações expostas no Livro Primeiro. De fato, este é todo revolucionário, na medida em que o autor não se atém apenas às demonstrações etio-patológicas das doen- 
ças que grassavam no país na época, mas as estuda em seu conjunto, contextualizadas no meio ambiente em que ocorrem. As características do livro ora em pauta, assim como os fundamentos que lhe deram sustentação, são assim resumidos pelo Dr. Fernando São Paulo, Catedrático de Terapêutica Clínica da Faculdade de Medicina da Bahia (em 1948):

Médico seiscentista, Piso vinculava o pensar ao valor da astrologia, da astronomia, à estima da alquimia; mas, no proceder, no operar objetivo da profissão, tomava como ponto rígido de apoio a orientação vetustíssima de Hipócrates, assimilada consoante o espírito da época. Por consequência, gerou a substância do Livro Primeiro do seu trabalho, com um subtítulo esclarecedor, como se fôsse dístico arqueado sôbre a feição hipocrática: trata dos ares, das águas e dos lugares do Brasil. Este Livro Primeiro afigura-se-nos um prelúdio; é o que se imagina, revendo-o, após a leitura sossegada da obra, no seu todo. Em vez da narrativa monótona dos fatos observados, num registro quase estático, o concerto das notas se processou ao vivo, no movimento legitimado pelas características do meio fisico, do ambiente cósmico, do homem encimado pelo expoente cultural. E o mérito da obra transbordou, ultrapassando a medicina pura. (São Paulo, 1948, p. 333)

Piso tinha razão em proceder ao estudo das patologias não deixando de relacionar sua etiologia aos elementos de cunho ecológico, uma vez que o meio ambiente lhes atribui, por vezes, fisionomia particular. Nesse livro, o médico batavo discorre sobre as principais doenças que acometiam as populações brasileiras da época. Distribui os dados em 22 capítulos temáticos, sendo conciso e direto em sua redação. Preocupa-se mais em explicar terapêuticas, expõe os remédios utilizados pelos portugueses e, sobretudo, pelos indígenas, fazendo um contraponto com seus próprios conhecimentos científicos. Por um lado, não deixa de render justa homenagem ao conhecimento médico dos silvícolas e de elogiar sua farmacopéia: lembra que esses povos curavam inúmeros males com medicamentos provenientes de 
uma planta apenas (simplices) e que os curandeiros indígenas desdenhavam dos remédios complexos, que se vendiam nas boticas da época.

A recriminação do autor aos cientistas da época por seu pouco empenho em estudar venenos e antídotos encontra no Livro Terceiro uma contribuição do médico a esse campo. O autor inicia esse livro discorrendo sobre a abundância de venenos existentes na natureza e discorda de Plínio quando este diz que a vocação primeira do veneno é aliviar o homem de males insuportáveis, auxiliando-o a dar cabo da vida. Piso é de opinião de que para cada veneno exista um antídoto. Mais: este muito freqüentemente provém do mesmo animal ou planta que produz o elemento mortífero.

Lembra também que inúmeras espécies da flora ou da fauna são nocivas à saúde e provocam a morte para os homens, mas não para certos animais. Explica ainda que algumas plantas, como a mandioca, por exemplo, podem ser um perigo para o homem in natura, mas, se tratadas, tornam-se alimento saboroso e nutritivo.

Em sua constante preocupação em testemunhar em favor dos silvícolas enquanto sábios na arte de curar (embora bárbaros em tudo o mais), Piso informa que "muitos outros venenos semelhantes aqui são produzidos, muito melhor conhecidos dos bárbaros do que dos europeus e sábios" (Piso, 1948, p. 47).

Em alguns momentos deixa seu racionalismo e objetivismo de lado para testemunhar que algumas atividades praticadas pelos aborígenes, baseadas em crendices e superstições, deram realmente o efeito por eles predito. Isso não significa que Piso fosse supersticioso; ao contrário, ressalta que seu relato vem no sentido de reunir dados para que se possa proceder a uma análise científica que dê sustentação ao que aparentemente foi fruto de magia ou de ação do sobrenatural. 

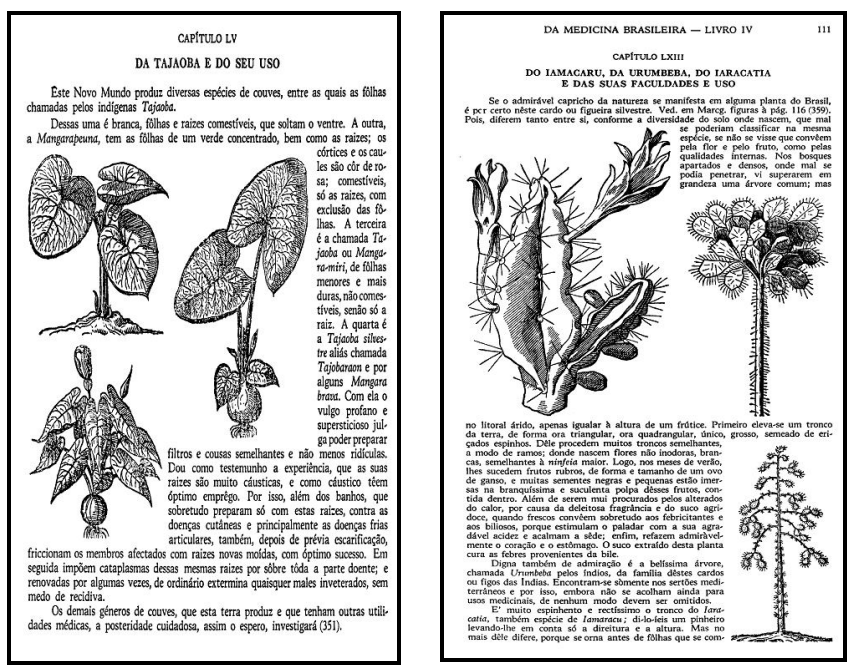

A parte mais longa e detalhada do trabalho de Piso é a que se dedica às faculdades dos símplices. De fato, o Livro Quarto, que apresenta esses dados, compõe-se de 104 capítulos temáticos, ricamente ilustrado com 110 figuras e ocupa 76 das 133 páginas da De medicina brasiliensi. Cada capítulo descreve as características fisiológicas das espécies da flora brasileira e suas propriedades medicinais.

O primeiro deles é consagrado à cana-de-açúcar, ou, mais especificamente, não apenas a planta em si é descrita, mas todo o processo de elaboração do açúcar. A atenção especial dada a esse produto não é sem propósito, uma vez que esse foi o motivo maior da escolha da região de Pernambuco para a invasão holandesa. Nesse sentido, a descrição de Piso é detalhada, apresentando, inclusive, ilustrações dos engenhos:
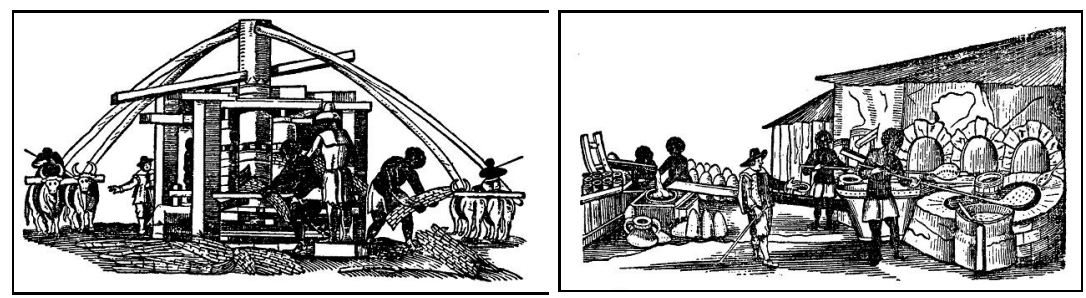

TRADTERM, 11, 2005, p. 255-307 
$\mathrm{O}$ autor pouco se atém às propriedades medicinais do açúcar, mas faz observações interessantes sobre esse produto, observações até hoje válidas:

Sôbre as aplicações médicas do açúcar, por serem na máxima parte conhecidas dos europeus, bastem poucas palavras. O suco da cana verde é frio, e muito mais durável e eficaz sendo distilado em alambique; cura muitos males dos olhos, bem como ardores do figado e rins. Mas tendo essa medula da cana passado por tantas transformações antes de, repurificada, ser reduzida a grãos, perde a sua primeira natureza, e mesmo adquire outra, mais grata ao paladar do que profícua para a saúde. Pois o açúcar, enbranquecido pela acção intensa da fortíssima lixívia, é certo mais agradável ao gôsto, mas conserva uma qualidade bastante acre, má para as vísceras e a cabeça.Por isso aquêle que, para o bem da saúde, se aplica na cozinha ou na farmácia será bom repurificá-lo ainda um tanto, afim de, conservando suas virtudes ingénitas, dulcificar mais fortemente os xaropes, os electuários e medicamentos semelhantes. E, antes, o açúcar vermelho, aliás tido como inferior (assim como o im-portado da Ilha de S. Tomé, isento de tôda lixivia), não deve ser desprezado, sobretudo nos clisteres. O açúcar, pois, embora quente e úmido em primeiro grau, sendo porém tanto mais quente quanto mais antigo e defecado, converte-se mais fàcilmente em bile, e mais intensamente desune e dissolve. Quanto ao novo, é útil não só para o peito e estômago, mas também para a bexiga e rins. Enfim, em todo condimento dos doentes, deve ser de muito preferido ao açúcar velho e ao mel. (Piso, 1948, p.60)

Essas notas, escritas em 1648, revestem-se de grande atualidade. Com efeito, inúmeros são os nutricionistas de nosso século a desaconselharem o consumo excessivo de açúcar refinado. Sugerem sempre que se dê preferência ao mascavo que, menos tratado, guarda mais propriedades nutricionais. A pouca demanda por este último se dá pelo mesmo argumento que Piso levan- 
tou: o gosto marcante do açúcar mascavo modifica o sabor dos doces e sucos. Por isso a população prefere o refinado, embora se saiba que seja menos indicado para a saúde.

O segundo capítulo é dedicado à descrição da mandioca. Este, assim como o do açúcar, é razoavelmente longo, se comparado com os demais. Aqui também Piso se atém à descrição minuciosa do processo de purificação da raiz e de produção de sua farinha, esta última ilustrada no capítulo dedicado à planta, como se vê abaixo:

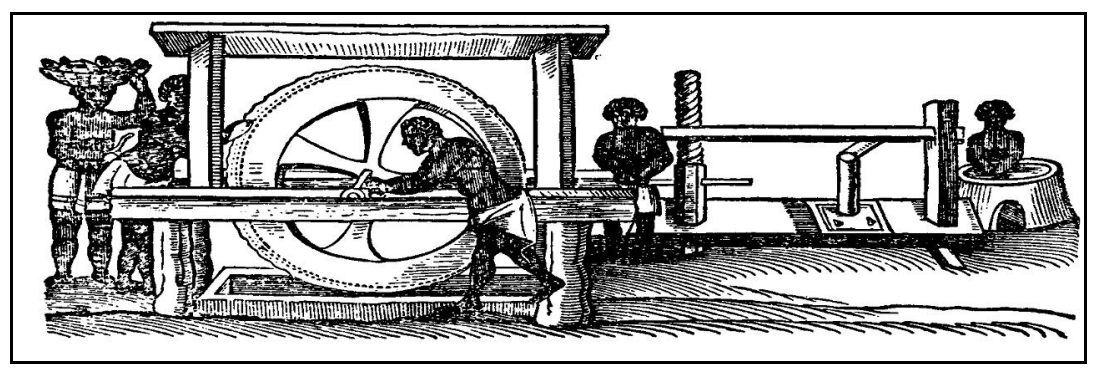

Neste caso também vemos como motivo para tão grande atenção o fator econômico: a mandioca encontra-se até hoje na base da alimentação do brasileiro e constituía, na época, uma candidata a ocupar, junto com a batata, um lugar fundamental na cozinha européia, carente de produtos resistentes ao frio. No que concerne às propriedades medicinais, Piso alerta para o fato de ser venenosa para o homem se consumida sem o devido preparo, largamente conhecido das populações brasileiras.

Um grande número de plantas da terra é estudada no Livro Quarto, entre gêneros e espécies, destacando sempre o autor os perigos e virtudes que oferecem à saúde do homem.

\subsection{O discurso terminográfico na obra de Piso}

Existe em Piso, assim como em praticamente todos os naturalistas, uma preocupação com a língua. $O$ fato de seu objeto de estudo constituir-se de elementos ou questões ligadas a uma realidade desconhecida ou pouco conhecida do público-alvo de sua obra obriga-o a tratar, de um modo ou de outro, as unida- 
des terminológicas que designam esses elementos. Nesse sentido, o autor é conduzido a lançar mão de alguns recursos que são característicos de um discurso lexicográfico (em sentido geral) e, como veremos mais adiante, mesmo terminográficos.

\subsubsection{Sinonímia, equivalência e etimologia}

Freqüentemente o autor fornece informações de caráter lingüístico ou metalingüístico, notadamente no que concerne às diferentes designações de uma mesma espécie da flora ou da fauna. Essas designações podem pertencer a uma mesma língua ou a linguas distintas.

\subsubsection{Sinonimia.}

Sem entrar, no âmbito deste trabalho, em discussões mais aprofundadas sobre o conceito de sinonímia, podemos afirmar que, na obra de Piso, inúmeras são as situações em que o autor indica termos que designam o mesmo conceito (ou o mesmo objeto referencial) em um contexto intralíngua. Exemplos:

$\mathrm{Na}$ foz dos rios, onde a água marinha em cada maré crescente inunda o pantanal, é êste percorrido por imensa multidão de ostras e carangueijos, e de tal modo bloqueado por um género de árvores tortuosas chamadas Guaparaiba ou Mangle, que se torna completamente impenetrável ao caminhante. (Piso, 1948, p. 6)

Segue-se agora a árvore silvestre Embira ou Pindaíba, como the chamam os indios. (Piso, 1948, p. 80)

Alguns portugueses the deram o nome de Pao velho e Pao mole por ter o córtice muito mole e rugoso. (Piso, 1948, p. 90)

Não diferente da clematite, sarmento tenaz e mui longo, ora trepa elegantemente pelas árvores vizinhas, ora repta pelo chão, como uma cobra, esta erva; a plebe portuguesa lhe chama Cipó das Cobras, pela semelhança com a co- 
bra, e Erva de Nossa Senhora, pelas eximias virtudes e prestâncias. (Piso, 1948, p. 105)

Os ferocíssimos enxames de vespas, que nidificam nas árvores, gostam de perseguir, não o gado, mas os viandantes, embora êstes ponham-se a salvo; mas quando irritadas, não poupam nem os tropeis de cavalos, e são chamadas pelos espanhois mariposas ou maribondas. (Piso, 1948, p. 43)

As observações sobre sinônimos podem se dar sobre termos em língua indígena, em português ou em espanhol, como pudemos verificar nos exemplos acima. A riqueza vocabular no domínio da Zoologia e Botânica deve-se a alguns fatores, dentre os quais se destacam a origem dos termos, que podem provir de línguas de povos aborígenes brasileiros distintos (chamados por Piso, de modo geral, indigenas) e a situação em que uma planta ou animal seja muito comum em uma região ou importante para uma população, acabando, então, por receber denominações diversas, dependendo do aspecto que se deseja colocar em evidência, como no caso de Cipó das Cobras, pela semelhança com a cobra, e Erva de Nossa Senhora, pelo auxílio que se crê que a santa dê para que os pacientes sobrevivam.

\subsubsection{Equivalentes}

Em inúmeros momentos o autor aponta equivalentes em línguas diferentes, notadamente em indigena, português e holandês, mas também em grego, espanhol e até mesmo em congolês, como podemos observar nos exemplos abaixo:

Além dessa, a Tatajba ou Pau amarelo, a Arariba, de casca vermelha, o Jacaranda, a Antuniba ou cedro branco, e muitas outras, óptimas para a feitura e construção de embarcações impermeáveis à água e de longa duração. (Piso, 1948, p. 6)

Boitiapô para os indios; para os portugueses, Cobre (sic) de Cipó, é serpente apenas da grossura de um braço, de 
sete pés de comprimento, cor azeitonada, mantém-se de rãs. (Piso, 1948, p. 49)

Chamam-lhe os indios Ibiboboca ou cobra bela; os portugueses, Cobre de Corais; tem o comprimento de dois pés, da grossura porém do polegar, cor nívea, pintalgada de manchas negras e vermelhas. (Piso, 1948, p. 49)

$\mathrm{O}$ que ainda hoje se pratica para a abertura de estradas nos desertos; donde se transportam para cá, com o fito no lucro, tantas árvores mui odoriferas e prestantes pelas suas côres e tintas variegadas e outras exímias utilidades, como á árvore $\alpha \alpha \tau^{\prime} \boldsymbol{k} \xi \boldsymbol{x}_{\grave{\eta} \boldsymbol{\nu}}$ (por excelência), chamada Ibirapitanga pelos brasis, conhecidíssima pela sua tintura rubra. (Piso, 1948, p. 6)

As terras ressequidas pela sua esterilidade produzem aquelas admiráveis ervas acima descritas; ou melhor, cordas

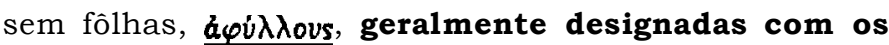
nomes de Timbo, e Cipo, que pela sua flexibilidade e resistência fazem para os ferreiros e cesteiros as vezes de ataduras; e quando pisadas, para os pescadores, curtidores e construtores de naus, as do sumagre e da estôpa. (Piso, 1948, p. 6)

Os peixes enfim ou são dessecados ao Sol ou preparados com sal (que aqui recolhem mui copioso nas salinas) e se conservam como provisões e salgados; entre êsses sobresaem os curima parati (Herders, dos holandeses). (Piso, 1948, p. 12)

O chamado Cunapu, Nero pelos portugueses e Jacob Evertsz pelos holandeses, se encontra tanto no mar como nos rios. (Piso, 1948, p. 12)

Além dêsses os lámias, chamados pelos brasis Cacaon, pelos holandeses Haven, e os serras, êles os denominam Araguaqua e nós Swaertfisschen, e que ocupam o primeiro lugar entre os vorazes. (Piso, 1948, p. 13)

O Inhame de S. Tomé, denominado pelos índios Cará e pelos congolenses Quiquoaquecongo, é planta de caule quadrado e um pouco torto de espaço a espaço. (Piso, 1948, p. 104) 
Há momentos em que a indicação de equivalentes também se faz acompanhar da de sinônimos em uma das línguas, como no caso de:

A vibora Ibiiara (vede a figura no Marcgrávio) os portugueses lhe chamam Cobra Vega ou Cobra de dos Cabeças, por parecerem ter duas cabeças, o que é falso. (Piso, 1948, p. 49)

Aqui, Piso aponta os equivalentes entre indigena e português de denominações de uma determinada cobra, indicando também sinôminos nesta última língua. O contrário também ocorre, como podemos verificar no exemplo abaixo:

Boiguaçu ou Iiboya, sem dúvida a máxima de todas as serpentes, tamanha quási como o peito de um homem, chamada pelos portugueses Cobre (sic) de Veado, por devorar cabras inteiras, mais sorvendo-as que as mastigando. (Piso, 1948, p. 48)

Desta feita, o autor indica sinônimos em indígena e um único equivalente em português. O mesmo ocorre ainda entre o indigena e o espanhol:

Em primeiro lugar, a serpente Boicinininga, chamada pelos espanhóis Cascavel e Tangedor, por emitir da cauda um sonido como de guizo; vê-se tanto pelas estradas como pelos lugares desertos; move-se em tão célere reptação, que mais parece voar. (Piso, 1948, p. 47)

Outro caso interessante é o que segue:

Os povos mediterrâneos chamam-lhes [um tipo de mandioca, suas folhas e caule] Cuguacucuremia; e os litorâneos, Cuacu-mandijiba. (Piso, 1948, p. 63)

Nessa citação vemos o autor indicar duas designações para o mesmo tipo de planta, que se parece com uma mandioca sel- 
vagem. Quando Piso fala de povos mediterrâneos e litorâneos, na verdade faz menção a povos indígenas que se localizam em regiões diferentes do Brasil, nas quais o pesquisador procedeu a estudos. Nesse sentido, se considerarmos, como Piso costuma fazer em toda sua obra, os indigenas como uma categoria única, estariamos diante de uma sinonímia. Consideramos, porém, que existem (ou, pelo menos, existiam no século XVII) inúmeros povos aborigenes do Brasil e, mesmo pertencendo a um grande tronco tupi-guarani, pertenciam a nações distintas, com línguas marcadas por particularidades. Assim, no caso da citação acima, preferimos considerar os termos Cuguacucuremia e Cuacumandijiba como equivalentes e não como sinônimos.

Há ainda uma observação lingüística de Piso que nos chamou a atenção:

No atinente às variolas e ao sarampo (que os portugueses designam com um mesmo vocábulo - besigas). (Piso, 1948, p. 38)

Trata-se, aqui, de uma diferença de visão de mundo que ganha expressão na língua: os portugueses não distinguiam, na época, o sarampo da varíola, chamando ambos de besigas. É interessante ressaltar que esse tipo de situação é muito comum ainda nos dias de hoje nos domínios especializados. Melhor dizendo: nossas pesquisas sobre a terminologia da Medicina e mesmo da Dermatologia (um domínio mais restrito que a primeira) conduziram-nos a observar que, em incontáveis situações, alguns especialistas, de uma mesma nacionalidade, consideram como uma mesma doença o que outros consideram como patologias distintas, e vice-versa; a situação se complica quando se procede a pesquisas em autores de nacionalidades diferentes. Assim, a questão lingüística da designação dessas doenças no mesmo idioma ou em línguas diferentes depende do recorte conceitual de cada especialista da matéria ou do recorte cultural que cada povo dá do objeto em si. 
4.2.3. Etimologia e variantes

Em diversas situações, a indicação de sinônimos ou de equivalentes se faz acompanhar de informações, de caráter metalingüístico, sobre a etimologia ou, mais propriamente, sobre a motivação da designação, como nos seguintes casos:

Entre as doenças crônicas é comum no Brasil a que ataca os nervos e produz profundo torpor dos membros. Os portugueses lhe chamam Air ( $\mathrm{sic}$ ) por nascer da inclemência do ar, de uma incompleta obstrução e da intempérie fria das partes nervosas. (Piso, 1948, p. 23)

Nos bosques arenosos e sáfaros se encontra uma árvore gomífera, chamada pelos bárbaros Icicariba, por causa da lágrima que destila, denominada por êles Icica, e Almaciga pelos portugueses. (Piso, 1948, p. 67)

Êste arbusto gutífero, pequeno e tenro, é chamado pelos portugueses Pao de Lacra, porque lhe deflui do córtice uma certa goma ou guta viscosa. (Piso, 1948, p. 69)

Os exemplos acima não fornecem, em alguns casos, exatamente informações de caráter etimológico, mas dados a respeito da motivação das denominações. Situações há em que Piso questiona categoricamente os mesmos, como em:

A vibora Ibiiara (vede a figura no Marcgrávio) os portugueses lhe chamam Cobra Vega ou Cobra de dos Cabeças, por parecerem ter duas cabeças, o que é falso. (Piso, 1948, p. 49)

A significação das denominações é, assim, uma preocupação de Piso, evidenciada em seus constantes comentários sobre os termos.

Em nosso estudo pudemos verificar que um outro tipo de observação de caráter lingüístico feito pelo autor concerne ao registro de variantes ortográficas, como ocorre no título do Cap. XLVII Do betys, ou betre, e das suas faculdades (Piso, 1948, p. 99). Cumpre, todavia, ressaltar que esse foi o único exemplo que 
encontramos, não sendo esse, portanto, um aspecto lingüístico de grande interesse ou preocupação do autor.

Baseados nos casos acima, podemos afirmar que na obra de Piso existe uma preocupação com aspectos lingüísticos que são, normalmente, objeto de tratamento em dicionários. De fato, estes costumam apresentar sinônimos e, em obras bilíngües ou multilingües, equivalentes em um ou mais idiomas. A etimologia também é um dado que costuma ser fornecido pelos repertórios. Vemos, portanto, no tratamento dado por Piso à terminologia designativa de espécies da flora e da fauna brasileiras e de doenças comuns ao Brasil da época, uma manifestação do discurso lexicográfico, embora, de modo algum o autor tenha tido intenção de produzir um dicionário.

\subsection{O fechamento do texto terminográfico}

Muitos termos que designam espécies endêmicas da flora e da fauna brasileiras são apenas mencionados no Livro I, sem nenhuma explicação ou paráfrase sinonímica, como ocorre nos seguintes casos:

Muitas árvores e frútices produzem òptimamente flores e frutas durante quási todo o ano, e nêles se podem ver ao mesmo tempo a primavera, o verão e o outono. Dessas sem contestação as principais são o Murucuya, a Mangaba, a Pacoba, a Banana, a Ianipaba, a Araca, a Pindova, o Coceiro, o Mamaon, os Pinhoens, a Piementa. Às quais se acrescentam a videira, o limoeiro, a laranjeira (38), e muitos legumes, raizes e hortaliças trazidos de Portugal e de Angola outróra, e últimamente da Holanda; cultivados agora em tôdas as hortas e usados comumente na cozinha. (Piso, 1948, p. 5)

Algumas árvores, e certo das mais nobres, como o Acaju, o Caja, a Ubipitanga, a Anda, o Zabucajo, o Murecy, a Ietajba, o Araticu, a Guabiraba, a Figueira e a Murta americana; o fruto Ananas e outras florescem só uma vez ao ano; e pela primavera, cêrca de outubro, tomam a bro- 
tar, logo rebentando em frutos de tamanho médio apenas, quando o Sol entra no Capricórnio; duram além de três meses, depois caem em repouso. (Piso, 1948, p. 6)

Finalmente, batendo uns contra os outros os paus Caraguatá, da Imbaiba e de outras plantas ferruláceas, que crescem nesses mesmos lugares, os bárbaros fazem petiscar lume mais brilhante o que de um pedernal ferido. (Piso, 1948, p. 6)

Os termos de origem indígena são destacados no texto por meio de itálico, mas sobre os mesmos ou sobre os objetos que os primeiros representam lingüisticamente o autor não dá mais detalhes descritivos. Essa despreocupação encontra uma possível explicação no fato de que muitas dessas espécies são tratadas amiúde nos Livros seguintes. O autor conta, assim, com um certo fechamento do texto terminográfico (lexicográfico), como ocorre nos dicionários. Este pode ser assim compreendido:

As definições devem veicular as informações necessárias para a total compreensão do conteúdo semântico-conceptual da entrada. Entretanto, nem sempre são capazes de suprir todas as necessidades de decodificação, já que, por vezes, nelas são empregadas unidades lexicais desconhecidas do leitor. Nesse sentido, coloca-se a questão do fechamento do texto lexicográfico ou terminográfico, ou seja, da decodificação, por meio da macroestrutura, de todas as unidades lexicais ou terminológicas inscritas na definição.

Em Medicina, por exemplo, os termos próprios dessa área do saber são muito freqüentemente descritos por enunciados definicionais que contêm termos da Biologia. A questão que se coloca nesse caso é: a nomenclatura do vocabulário deve contemplar todas as unidades terminológicas da Biologia e da Medicina, para que o leitor possa entender totalmente as definições? Ou a nomenclatura deverá conter apenas os termos próprios da Medicina e todos os de Biologia devem ser procurados pelo leitor em 
outros dicionários? Se o terminógrafo decidir pelo tratamento dos termos da Biologia, estará adotando um sistema fechado. Caso opte por definir apenas os termos específicos da Medicina, remetendo o leitor a outros repertórios, estará optando pelo sistema aberto.

É posição majoritária entre os terminógrafos que a decodificação em sentido único - da macroestrutura à microestrutura - constitui uma tarefa suficientemente dificil e que o total fechamento da cadeia interpretante (fechamento do texto terminográfico) é praticamente impossivel de se obter. $O$ sistema aberto, é portanto, considerado como o mais viável, sobretudo porque um dicionário não existe sozinho. Ele faz parte de um conjunto de repertórios mais vasto, capaz de suprir as necessidades de compreensão geral de um conjunto terminológico específico. (Barros, 2004, p. 154-155)

Assim, se um leitor busca uma informação em um dicionário e, no enunciado lexicográfico do verbete consultado, depara-se com uma palavra que lhe é desconhecida e que o impede de compreender o significado da entrada, este procura a nova unidade lexical no próprio dicionário (na lista das entradas), completando, desse modo, a decodificação do enunciado definitório inicial e obtendo a informação que deseja. Da mesma maneira, o leitor da obra de Piso que não conhecer os termos Banana, Ianipaba, Pinhoens, Murecy, Mandioca e outros poderá obter os dados necessários à compreensão em capítulos especialmente dedicados a essas plantas. (exemplo: Livro Quarto, Cap. II. Da mandihoca; Cap. XV. Da ianipaba; Cap. XXVII. Da bacoba e da banana; Cap. XXXII. Do mureci; Cap. XL. Dos pinhones do Brasil etc.) ou em capitulos mais genéricos, que englobam a espécie citada (exemplo: Livro Quarto, Cap. X. Das palmeiras e das suas várias espécies, onde a Pindova e o Coceiro (coqueiro) são descritos).

Nesse sentido, De medicina brasiliensi apresenta um certo fechamento da cadeia interpretante comum aos dicionários. Também como ocorre nestes, na obra de Piso há limites para esse fechamento e nem tudo é descrito em detalhes. 
Por outro lado, é preciso lembrar que esse trabalho inserese em uma obra maior, a Historia naturalis brasiliae, onde se encontra outra, a de Marcgrav, a qual dedica três livros às plantas brasileiras. Assim, Piso conta também com o chamado sistema aberto, ou seja, conta com que os dados desconhecidos do leitor que não puderem ser esclarecidos em seus livros tenham chance de serem encontrados nos de Marcgrav.

\subsection{Disposição gráfica do texto}

Os textos dos Livros Primeiro e Terceiro se apresentam em forma corrida, sem separações por capitulos, temas ou qualquer tipo de recurso gráfico que disponha os enunciados isoladamente. Os Livros Segundo e Quarto, por sua vez estruturam-se em capítulos, a cada um correspondendo um tema, como podemos observar no índice dos Livros em questão:

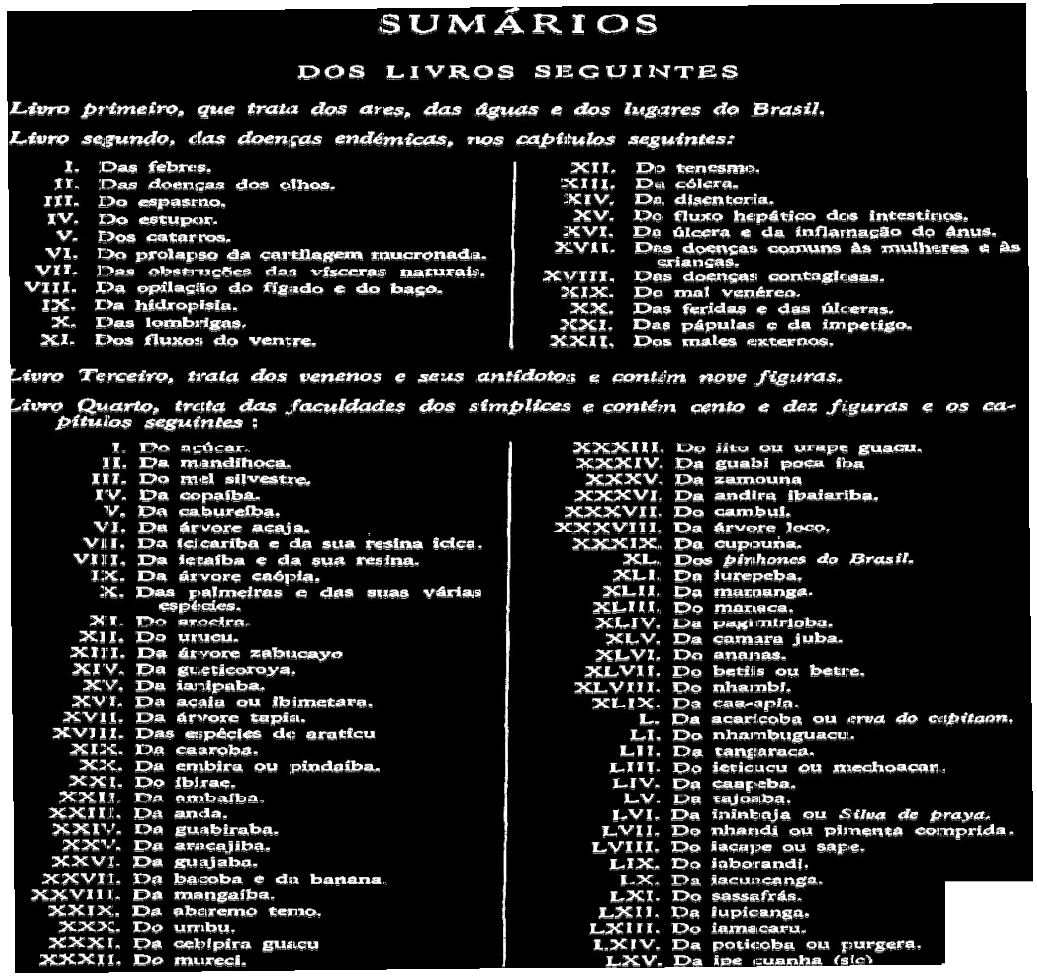

TRadTerm, 11, 2005, p. 255-307 


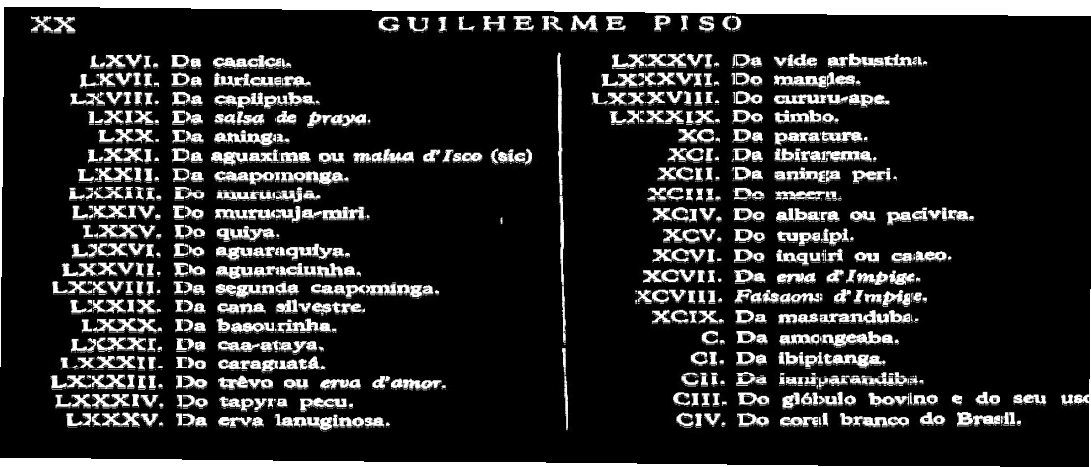

No interior desses capitulos, muito freqüentemente os dados são dispostos em modo semelhante ao de um verbete de dicionário, como podemos observar na figura abaixo:

\section{CAPÍTULO XXII}

\section{DOS MALES EXTERNOS CAUSADOS POR ALGUNS INSECTOS}

\section{BICHO DOS PÊS}

Esta terra cria uns minutíssimos vermículos chamados bicho pelos portugueses e tanga pelos indígenas. Muitas vezes com prurido e raro com dor, criam-se nas extremiciades dos dedos dos pés. Atacarn sobretudo e de preferência os que andain descalços e perambulam por lugares arenosos, onde, por serem mui quentes, gostam de viver invisíveis; evitarn os pavimentos de pedras. A princípio fican latentes durante algum tempo no exterior da pele. Logo, causando grande prurido, sobretudio nas plantas dos pés, penetram sein dano e nela se acoutam. Nada têen de comum

DA MEDIOINA BRASTLETRA - LIVRO II

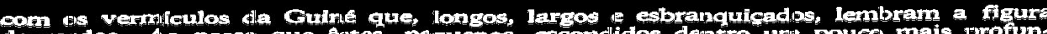
de eordas. Alo passp que estes, pequencs, escoudidos dentro win pouex mais protum-

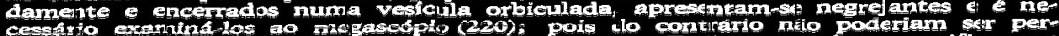

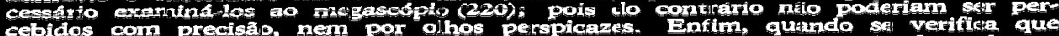

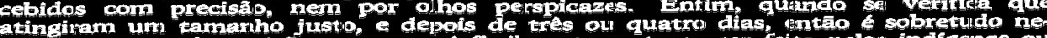

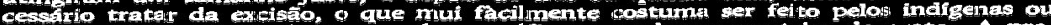

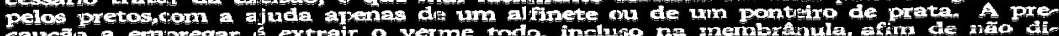

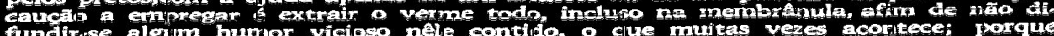

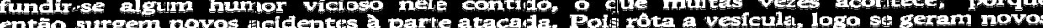

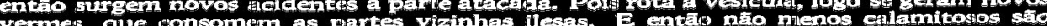

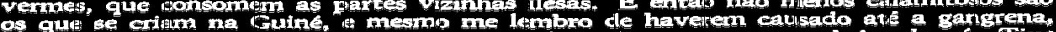

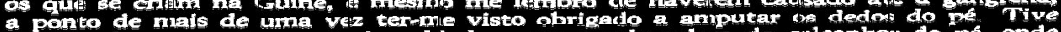

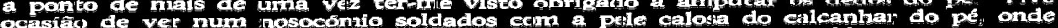

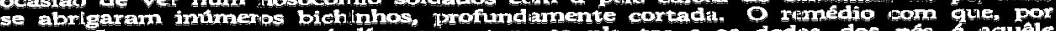

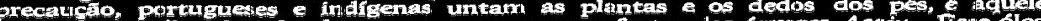

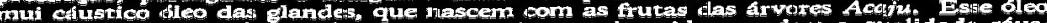

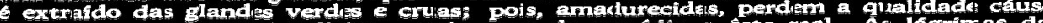

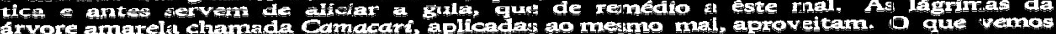
tanbem fazel a merinhagen eomo o pes ulos navios (221).

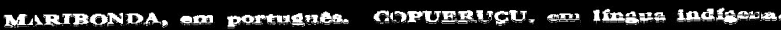

da femosiscimos enxames de vespas, que nidificam nas frvores, gostam de pere

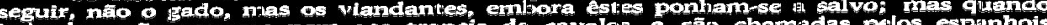

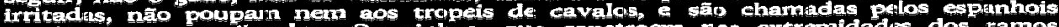

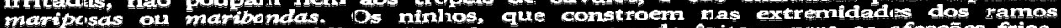

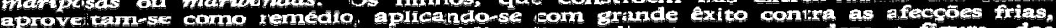

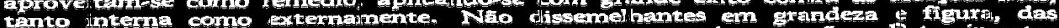

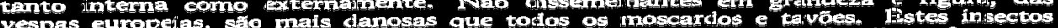
Vespas europies,

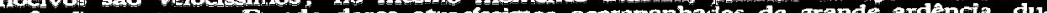

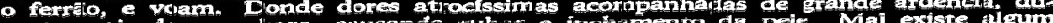

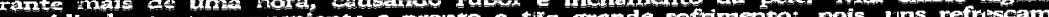

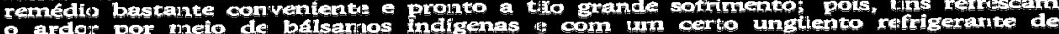

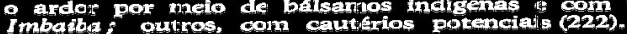

TRADTERM, 11, 2005, p. 255-307 
Fit, altm dsste, outro getuero de vermafculas alados, pretos e tato pequenos que

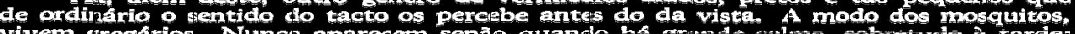

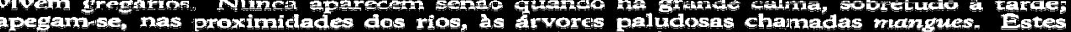

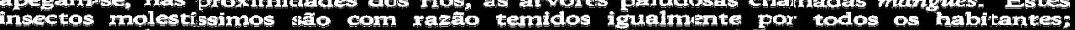

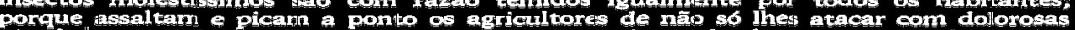

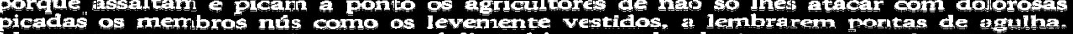

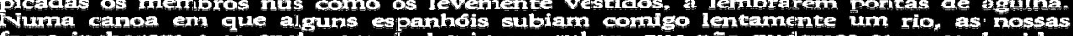

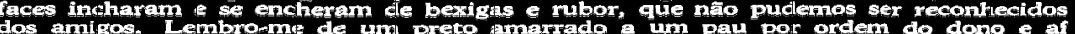
dos aruigos. Lembrome de urn preto amaxrado a um pau por ordem do dono e af

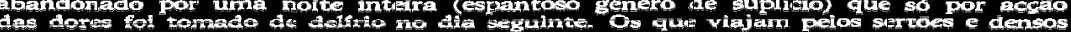

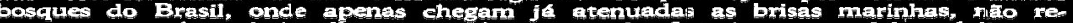

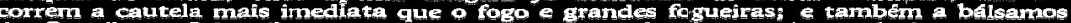
de Copabba e Caburaba, com que untam as membros nus. Antes de hora ne ma

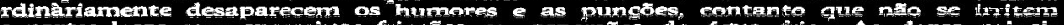

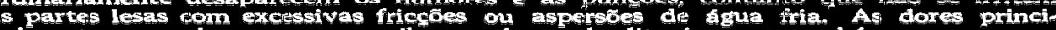
palmente se ecalman form mucilagen de canio fitorineo, e ramban com ia erva Paginirioba o Imbaba e com outros susos espessados do mesmo geneino, dota los de

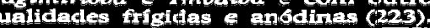

O Cap. XXII do Livro II, ilustrado pela figura precedente, inicia-se na página 42 e continua na página 43. Tem como tema os "males externos causados por alguns insetos". Diferentemente dos demais campos temáticos - que tratam os dados de modo unitário, ou seja, sem procederem a divisões internas, mesmo que discorram sobre espécies diferentes -, este capítulo dividese em subcampos temáticos, abordando o bicho dos pés, a marimbonda e os moscites.

Nesses casos, a forma gráfica atribuída a cada um desses termos assemelha-se em muito a verbetes de dicionários, compondo-se do seguinte programa de informações: Entrada: termo em português, em maiúsculas e em negrito: microparadigma constante; Equivalente: termo em língua indígena, em maiúsculas e em negrito: microparadigma não-constante (em bicho do pé, somente o termo em português é dado); Enunciado lexicográfico: microparadigma constante.

A separação entre os "verbetes" se faz por espaços em branco. Essa disposição no interior de um campo temático segue, inclusive, a ordem alfabética das entradas em português: $\underline{\boldsymbol{b} i}$ cho dos pés, marimbonda, mostices. As semelhanças com um dicionário ficam ainda maiores no Livro III, onde muitos dados relativos a espécies da fauna, venenosas ou perigosas à saúde do homem, são tratados isoladamente, assumindo a forma de verbetes. Para termos uma visão mais clara da questão, vejamos as páginas abaixo: 


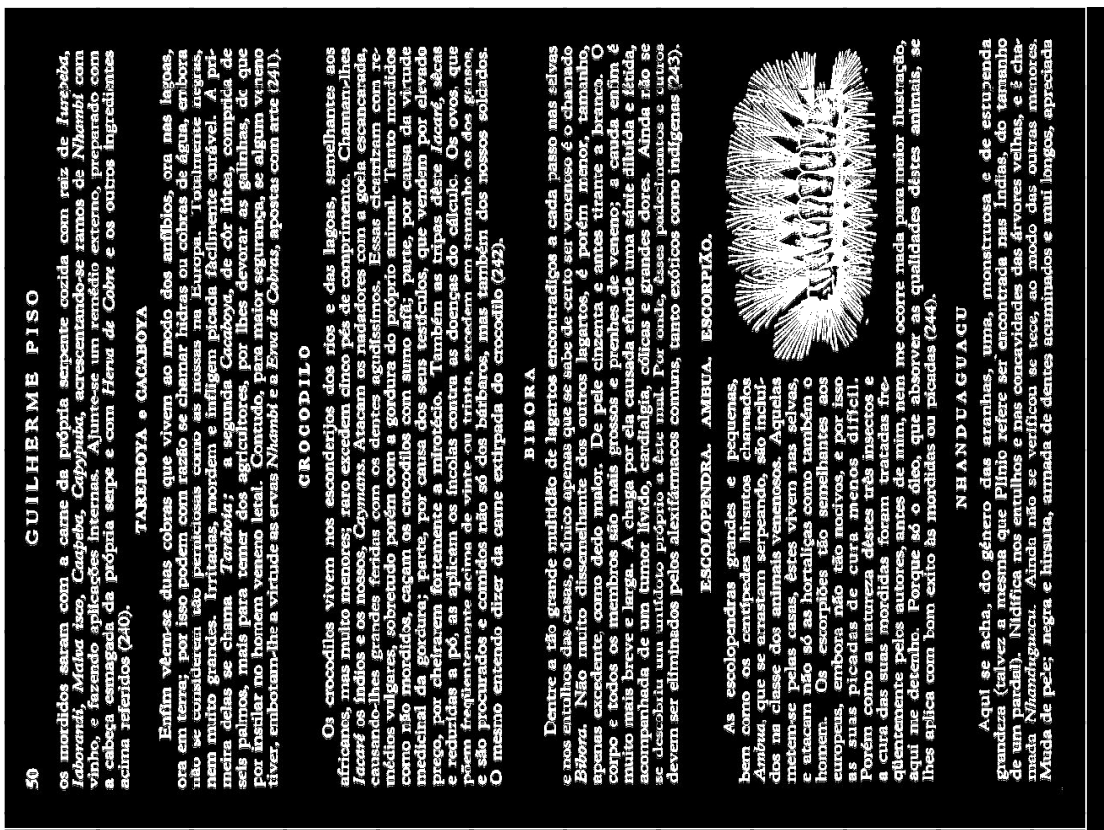

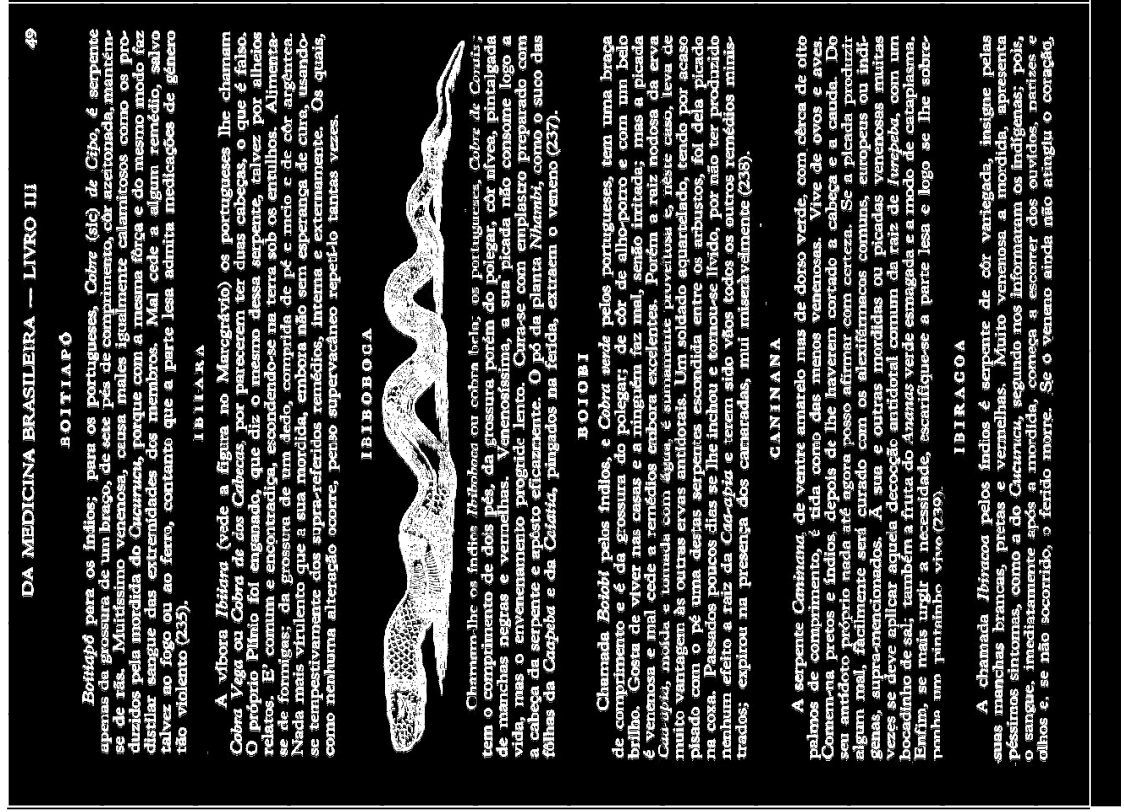


Como podemos observar nessas figuras, os dados são organizados em blocos separados entre si por espaços em branco, em forma de verbetes, que se seguem na vertical, organização típica da macroestrutura dos dicionários. Na horizontal, o programa de informações da "microestrutura" respeita a seguinte seqüência:

Entrada: em maiúsculas, em negrito, centralizada, acima do texto: microparadigma constante;

Enunciado terminográfico: microparadigma constante. Compõe-se das seguintes zonas:

- Entrada (em forma discursiva): termo em língua indígena: microparadigma não-constante;

- Equivalente (em forma discursiva): termo em português: microparadigma não-constante;

- Enunciado definicional e/ou enciclopédico: microparadigma constante;

- Ilustrações: microparadigma não-constante.

A ordem das entradas não é, todavia, a alfabética, e o princípio que rege a seqüência dos "verbetes" não fica totalmente evidente. O modelo de "microestrutura" dos "verbetes" não é homogêneo e os enunciados dos verbetes podem ser de natureza enciclopédica, lexicográfica e mesmo terminográfica.

\subsection{Enunciado enciclopédico}

Um primeiro tipo de enunciado que podemos apontar como característico de alguns "verbetes" é o puramente enciclopédico, como podemos observar no Capítulo XV. Do fluxo hepático do ventre. Este apresenta dados históricos, como os expressos na primeira frase do texto:

No ano de 1638 na cidade do Salvador na Bahia, assediada por meses excessivamente chuvosos, nenhuma calamidade assolou o nosso exército como um fluxo sanguíneo, algo diverso da disenteria pelos sinais e pela cura 
(vede sobre a causa desta doença Plátero e Senerto). (Piso, 1948)

Cumpre, no entanto, dizer que esse tipo de dado encontrase por vezes presente, mas não constitui um traço marcante na obra. Outro dado eminentemente enciclopédico/científico são as referências bibliográficas, que remetem a autoridades ou trabalhos no assunto, como a observação "(vede sobre a causa desta doença Plátero e Senerto)" (Piso, 1948) no texto acima ou mesmo em outro exemplo, como o "verbete" dedicado à opilação do figado e do baço:

A causa antecedente principal dêste mal é a penetração do frio, que paralisa a transpiração e a circulação; causa porém composta e mista, o dissoluto e desordenado modo de viver. (Hofmânio prova com elegância, que o ar atraido pela respiração não penetra menos o estômago e os intestinos, que os pulmões; Institut. pag. 354) (Piso, 1948, p. 28)

Por isso os imperitos atribuem ao peito a causa precípua e primeira do mal; embora possa dizer-se sem inexactidão, que o peito sofre por simpatia, pela respiração demasiado interrompida e difícil. Consulte-se um lugar digno de nota em Galeno 4 de locis affectis, cap. ult. (Piso, 1948, p. 28)

Esses são apenas exemplos de dados enciclopédicos presentes na obra de Piso. Outros tipos de dados dessa natureza que se verificam constantemente na obra concerne a procedimentos terapêuticos, como podemos observar no exemplo abaixo:

(Livro II, Cap. III. Do espasmo)

Antes de tudo, se nada de grave e nenhuma contra-indicação o obstar, deve-se praticar a venesecção; logo em seguida aplicar clisteres acres, reiterados algumas vezes. Depois, sudoríferos de alexifármacos, triaga, diascórdio, chifre de veado e ri-noceronte, e bolo arménio (147). Os 
sintomas e a cura mostram haver algo de maligno. Se o mal protrair-se é mister recorrer à decocção de salsaparrilha, da casca de guaiaco, da raiz de quina chamada Iupicanga, do sassafraz, do Iaborandi, do Bétele, do Nhambi e de outras ervas dos indigenas brasileiros, do mesmo género. A isso devem seguir-se banhos úmidos e sêcos, fumegações de estêrco de cavalo, com benjoim, ánime e semelhantes medicamentos arcmáticos (148). Depois de se lavarem bem os suores, devem fazer-se fricções fortes. Enfim, unções no pescoço, na espinha dorsal e partes vizinhas, com óleos e bálsamos apropriados, nativos e exóticos. $O$ doente sempre bem coberto permaneça em aposento quente, com o corpo continuamente a escorrer suor. Coma muitas vezes e pouco, por causa da queda das fôrças, e beba bebidas cálidas. Não raro, se se observarem as recomendações supra, vencerá nessa luta; sobretudo se sobrevier febre ou também fiuxo do ventre, que evacue a matéria convulsiva passada dos nervos para as veias (Hippocrat. lib. IV aforism. 57: a febre superveniente a um atacado de espasmo ou tétano faz passar a doença. E Coac. 358: convulsões aparecidas de repente a febre e os fluxos do ventre as fazem passar) (149). Do contrário, se o médico e o próprio doente ou os assistentes esquecerem as suas obrigações ou cometerem um êrro ainda levíssimo, antes de vencida a matéria pecante, certissimamente perderá a vida o doente. $\mathrm{O}$ que às vezes me lembro ter acontecido, estando êle com a bôca apertadamemte cerrada, e manifestando-se o intenso movimento convulsivo dos paroxismos, acompanhados de grandes dores e prantos. (Piso, 1948, p. 22)

O enunciado acima descreve os espasmos e os dados destacados em negrito referem-se ao tratamento que o autor recomenda. É natural que esse tipo de informação seja veiculada pelos "verbetes", uma vez que se trata de um Tratado de Medicina. Essa característica não é, porém, uma constante em todas as obras de mesma natureza, inclusive datadas do século XX. 
Assim, a orientação sobre o tratamento das doenças não é obrigatoriamente uma marca de todo e qualquer Tratado de Medicina, mas nem por isso deixam de existir obras que apresentem esse tipo de dados. Assim, a obra de Piso encontra-se, por um lado, dentro de uma norma própria de Tratados e Manuais de Medicina e, por outro, tem suas particularidades no que tange ao fato de indicar tratamentos para as doenças descritas.

Poder-se-ia argumentar que esse tipo de dado não mantém nenhuma relação com os encontrados em dicionários e, portanto, não teriam razão de se encontrarem nesta análise. Refutamos essa eventual colocação, visto que esse tipo de informação encontra-se presente em dicionários de áreas médicas do século $\mathrm{XX}$, como podemos observar nos exemplos abaixo: 


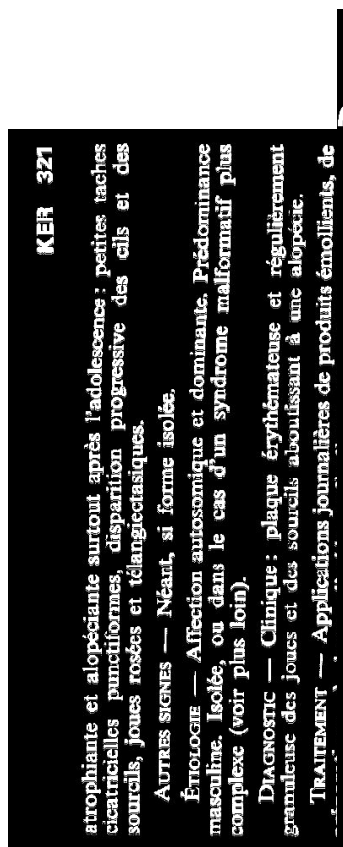

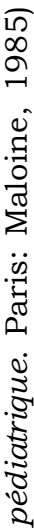

蕰商

要造

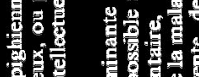

譬言

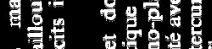

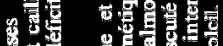

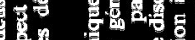

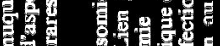

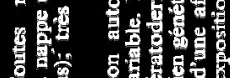

응

$18 \%$ 跑

me <

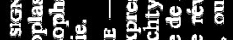

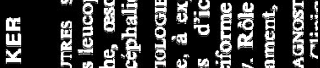

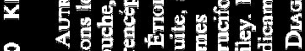

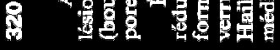



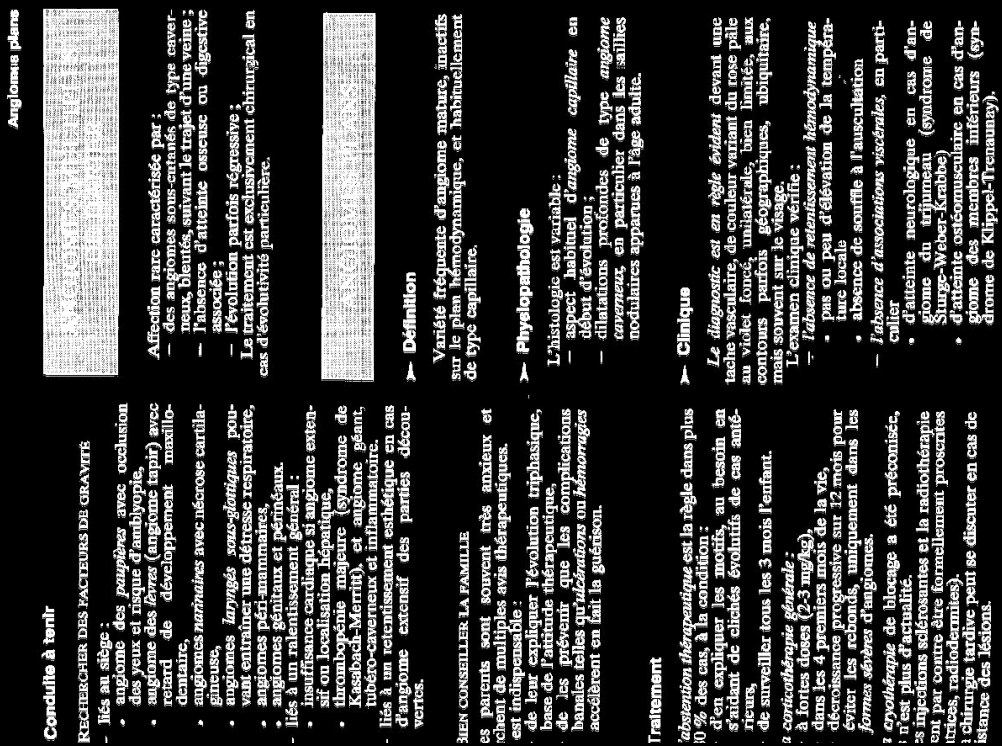

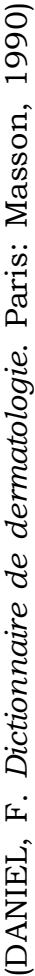

TradTerm, 11, 2005, p. 255-307 
Como podemos constatar pelas ilustrações acima, tanto o Dictionnaire de dermatologie pédiatrique, quanto o Dictionnaire de dermatologie, ambas obras francesas publicadas recentemente (1985 e 1990) por editoras de renome (Masson e Maloine), apresentam verbetes que, em seu programa de informações, contam com microparadigmas razoavelmente constantes dedicados ao diagnóstico, procedimentos clínicos e tratamento. Nesse sentido, podemos tranqüilamente traçar um paralelo entre a obra de Piso e alguns dicionários médicos de hoje.

$\mathrm{Na}$ obra do holandês, os enunciados também apresentavam freqüentemente elementos que não se atêm à descrição, mas dão voz ao cientista que explica seu trabalho: "com regularidade, aparecem no corpo dos verbetes, logo após as descrições propriamente ditas, uma narração marcada com tempo passado. É a voz do cientista natural em pleno ofício, relatando os métodos e processos da observação natural' (Nunes, 1996, p. 71-72). Como exemplo dessa propriedade, vejamos os casos abaixo:

O fruto amadurece no mês de abril e os índios o comem chupando-Lhe o suco e rejeitando-lhe a casca. Os macacos apreciam imenso essas frutas. Eu próprio colhi algumas bagas no mês de junho, e apenas começadas a germinar lancei-as na terra onde cresceram viçosas. Esta grande árvore abunda numa seiva densa e odorífera; cortando-se-lhe o córtice até a medula, pelo plenilúnio, destila tanta quantidade dela, que escorre, no espaço de três horas, cêrca de doze litros de óleo. (Piso, 1948, p. 65)

\section{Travei conhecimento com três espécies de Camara,} frutescentes; nascem em qualquer terreno, semelhantes não só pelo aspecto externo, mas também pelas virtudes naturais, consideradas como cálidas e sêcas no segundo grau. Só diferem por ser uma delas mais arborescente que as outras. (Piso, 1948, p. 97)

Os enunciados acima destacados constituem testemunhos do naturalista em ação, ou seja, o locutor é um cientista que faz observações, que descobre, que faz pesquisa de campo. 
Os enunciados definitórios

Em meio a dados enciclopédicos encontram-se verdadeiros enunciados definicionais, como em:

\section{CUCURUCU}

O Cucurucu é uma cobra grossa, côr cinzenta, por dentro amarela, pintalgada de manchas externas pretas, revestida de escamas idênticas às do Cascavel; de nove e raro doze pés de comprimento. Muitíssimo venenosa e grandemente temivel, embora os bárbaros lhe comam a carne preparada. O veneno lhe está sobretudo na cabeça, e por isso os indios cortam-lha o mais depressa possivel depois de morto, e cobrem-na com terra. O picado por êle é tomado de vertigem, tremores, cólicas, de líquios dos sentidos, febres ardentes, a que sucede enfim a própria morte, dentro de um dia natural e às vezes antes. Além das particularidades referidas é peculiar a esta serpente uma picada virulenta a ponto de corroer as veias e causar tanta inflamação e ardor, que a ferver o sangue promana em pouco tempo, dos narizes, dos ouvidos e até das mãos, pés e unhas. (Piso, 1948, p. 47-48)

Os cilindros e as pranchas pelos quais corre o suco expremido, bem como o conduto por onde cai, devem lavar-se duas vezes no espaço de vinte e quatro horas ou uma Tareffa (sic) (Tareffa é o espaço de terra, cuja quadra tem cêrca de vinte passos e produz tantas canas quantas se podem moer num dia natural). (Piso, 1948, p. 59)

Nos exemplos acima cucurucu e tareffa são colocados em posição de sujeito do enunciado definicional, seguidos da cópula é e de seu predicado definicional:

\begin{tabular}{|l|c|l|}
\hline $\begin{array}{c}\text { Entrada } \\
\text { (Sujeito) }\end{array}$ & Cópula & \multicolumn{1}{|c|}{ Predicado definicional } \\
\hline O Cucurucu & é & $\begin{array}{l}\text { uma cobra grossa, côr cinzenta, por dentro amarela, pintalgada de } \\
\text { manchas, ... }\end{array}$ \\
\hline Tareffa & é & $\begin{array}{l}\text { o espaço de terra, cuja quadra tem cêrca de vinte passos e produz } \\
\text { tantas canas quantas se podem moer num dia natural }\end{array}$ \\
\hline
\end{tabular}




\subsection{Definições lexicográficas}

Outros "verbetes" já apresentam uma estruturação do enunciado que em muito se assemelham às tradicionais definições, como em:

\section{J ARARACA}

Curta, esta serpente raro excede o comprimento de meio côvado; ostenta umas veias proeminentes na cabeça ao modo da víbora, e silva não diferentemente dela. Insigne pelas manchas vermelhas e negras; no mais, de côr térrea. Suas picadas venenosas não apresentam menores sintomas que as das demais serpentes, exceptos os de consumirem a vida lenta e sorrateiramente. A própria serpe, depois que infligiu a ferida, extirpando-se-lhe a pele, a cauda, a cabeça e as entranhas, e cozida em água de raiz de Jure peha. com sai, óleo, alho-porro, endro e temperos semelhantes, é comida pelos que picou, e lhes costuma ser de grande ajuda. Mas convém mais que tudo o Caatia, chamada com razão Hcrta de cobras; ministrada externa e internamente. fàcilmente cura das mordidas desta e de outras serpentes. Também são de óptimo préstimo os bagos da árvore Guibira, aplicados moídos às regiões mordidas. (Piso, 1948, p. 48)

Neste caso, o termo-entrada é jararaca, a cópula não é explícita e a primeira frase do "verbete" já é um enunciado definitório do tipo que se encontra na maior parte dos dicionários de Medicina modernos.

\subsection{Definições terminológicas}

Na obra desse autor, podemos encontrar, ainda, textos com características que se aproximam de "enunciados terminográficos", ou seja, o texto segue o modelo tradicionalmente indicado pela Terminologia como próprio dos dicionários terminológicos: gênero próximo + diferenças específicas.

A menção, retomada ou indicação do gênero próximo é, aliás, uma constante nos textos do Livro IV, uma vez que este se 
dedica à descrição das propriedades medicinais das plantas brasileiras e, para situar a espécie, nada melhor do que contextualizá-la dentro de um gênero, como se vê nos exemplos que seguem:

\section{DA COPAÍBA}

... A Copaiba é árvore silvestre e alta, de casca acinzentada; esgalha-se no alto, em ramos. Tem as fôlhas de meio pé de comprimento, maiores e menores, opostas duas a duas, mas com duas juntas na extremidade; oblongas, acumunadas, nervuras e veias um tanto avermelhadas, de um verde mais acentuado na face superior que na inferior. Na extremidade dos galhos maiores aglomeramse muitos rámulos, a que aderem as fôlhas em forma de frondes. Aí nascem as flores, seguidas de frutos, com a grandeza e a forma das bagas do loureiro; verdes a princípio, tornam-se negros depois de maduros, com pouquíssima polpa, sabor adocicado; separa-se-lhes fàcilmente a casca negra, mais grossa que a da fruta da ameixeira silvestre. Encerra uma pevide oval, dura, com uma amêndoa branca de sabor farináceo, mas não comestivel. O fruto amadurece no mês de abril e os índios o comem chupando-Lhe o suco e rejeitando-lhe a casca. (Piso, 1948, p. 65)

\section{DA ÁRVORE AMBAIBA E DAS SUAS FACULDADES}

Esta figueira silvestre raramente encontradiça nas florestas, gosta dos campos anteriormente cultivados, onde cresce nativa. $\mathrm{O}$ tronco único, mui liso e feruláceo, elevase a pequena altura. Como os europeus o sabugueiro, assim os índios, para todos os seus usos e diversões, cavam o pé desta árvore e, quando andam pelos sertões, friccionando a raiz, e com outras artes, produzem hàbilmente o fogo. Galhos raros e que só bracejam na extremidade, cingem-na a modo de coroa, com fôlhas raras, mas mui grandes, elegantes e recortadas. Rebenta em botões esbranquiçados, unidos em cachos, pénseis, envoltos em túnicas rosáceas; chegados à maturidade, fanam-se e caem, pelos meados do verão. (Piso, 1948, p. 81) ... 
Outra do mesmo género é a chamada arnbaitinga, mencionada por João de Laet (310), de ramos rubicundos, caule menos ôco, fôlhas porém ásperas a ponto de, a modo de lima, servirem para alisar certos objectos. Contém um licor oleoso, do mesmo uso e eficácia que o suco da Ambaiba. (Piso, 1948, p. 81)

\section{DA PAGIMIRIOBA E DO SEU USO NA MEDICINA}

Encontram-se no Brasil dois géneros de Pagimirioha, a que os portugueses chamam Herva de bicho, por causa do seu uso quotidiano. É considerada uma espécie de órobo (338). Nativa em qualquer terra, mas sobretudo na arenosa. Plantas frutescentes, de flor cérea, vagens finas compridas e delgadas. De um verde carregado, contêem umas sementes redondas e cinzentas. ... (Piso, 1948, p. 96-97)

Como podemos observar, os enunciados iniciam-se resgatando o gênero ao qual a espécie da flora brasileira descrita pertence. No caso da copaíba, o gênero próximo é "árvore silvestre"; no da ambaíba, é "figueira silvestre"; no da arnbaitinga, "outra do mesmo gênero"; e no da pagimirioba (ou herva do bicho) "espécie de órobo". Após a menção ao gênero, a espécie é descrita de acordo com suas diferenças específicas. Nesse tipo de definição, as características restritivas são apresentadas de modo que se diferencie a espécie descrita de todas as outras pertencentes ao mesmo gênero, dando àquela um caráter único. A definição terminológica estabelecida com base numa relação de inclusão semântico-conceptual que descreve o termo por meio de traços distintivos (características), chamada definição especifica ou definição por compreensão, é considerada como ideal para a elaboração dos vocabulários técnicos, científicos e especializados. Nesse sentido, os enunciados dos exemplos acima podem ser identificados às definições terminológicas. Em algumas situações, o caminho seguido pelo texto do autor é inverso: fala-se do gênero, indicando-se as espécies que a ele pertencem, como nos seguintes casos: 
Entre os animais venenosos do Brasil ocupam o primeiro lugar as serpentes, das quais ate agora se conhecem e enumeram cêrca de vinte: Boiguacú ou liboya, Arabó, Boiobi, Boicininga, Boitiapó, Boycupeccznga, Boipeba, Cucurucu, Caninana, Curucacutinga, Guinpaüagura, Ibjara, laca pecoaja, lbiboboca, Iararaca, Manima, Vona Tareiboya e Cacaboya, Amorepinima, das quais as três últimas são aquáticas. (Piso, 1948, p. 47)

Entre os frutos subterrâneos alimentares merecem o primeiro lugar os vulgarmente chamados Batatas, Inhame e Amenduinas. (Piso, 1948, p. 104)

Do Araticu, uma das árvores indígenas do Brasil, há várias espécies; dessas, as duas chamadas pelos índios Araticu-ponhe e Araticuapé pouco diferem. (Piso, 1948, p. 78)

Há várias espécies dêste arbusto, a que os indios chamam Maniiba e Manduba; embora pareça ao primeiro aspecto não se diferençarem entre si, contudo os agricultores experimentados as distinguem pela qualidade, pelo caule e pela côr, e lhes dão nomes diversos, cujos principais são os seguintes. A primeira espécie se chama Mandiiba-buara; a segunda, Mandiibparati, de raizes e troncos brancacentos; a terceira, Mandii-bucu; a quarta, Mandiibumana, a quinta, Aipi; a sexta Tapecima; a sétima, Arpipoca; a oitava, Mandijupeba; a nona, Macaxera. (Piso, 1948, p. 60)

As várias árvores altas chamadas Guetijs produzem frutos amarelos do mesmo género, com pouca polpa, cheios por dentro de uma grande pevide de figura oval. Pude ver pelo menos três espécies desses frutos - Guetitoroba, Gueri-miri e Gueticoroja, - todos comestiveis, mas pouco procurados, excepto o maior, de que agora tratamos, tido pelos magnatas como guleoseima. (Piso, 1948, p. 76)

Nesses casos, os enunciados se identificam com um outro tipo de definição previsto pela Terminologia, chamado por extensão (definições genéricas), os quais consistem "em enumerar todas as espécies que estão no mesmo nivel de abstração ou todos 
os objetos individuais que pertencem ao conceito definido" (Felber, 1984, p. 137).

Outra característica do estilo do autor no que concerne à descrição das doenças ou dos elementos brasileiros da natureza é o de, além de indicar o gênero ao qual pertence uma espécie ou indicar as espécies que pertencem a determinado gênero, Piso também os descreve por comparação entre si, como podemos observar nos exemplos abaixo:

As batatas são de diversas côres, mas de qualidades congéneres, nutritivas, e os naturais com grande vantagem servem-se delas como alimento. São grossas, doces e flatulentas; amadurecem precisamente no inverno por causa da muita umidade, e se cultivam só nas hortas. As fôlhas são grandes, glabras, de um verde concentrado, rastejantes sôbre a terra. Dão flores verde-pálidas por fora e brancas por dentro. Assim se pode ver em Marcg. pag. 16 (348). Os chamados Inhame são mais pesados e muito maiores, mas de qualidade inferior às Batatas, filamentosos e tuberosos, só procurados pelos pobres. (Piso, 1948, p. 104)

Assim, o Araticu-ponhe é árvore semelhante, pelo cáudice, pela configuração dos ramos e côr do córtice, à laranjeira, desta porém diferindo pelas folhas, flôres e frutos. As fôlhas têem cêrca de meio pé de comprimento, opostas entre si alternadamente, a página superior de um verde carregado, lustroso; a inferior de um verde-pálido; ... O Araticuape é quási completamente semelhante a éste; ambos produzem uns frutos agridoces, comestiveis, mas silvestres e frios, e por isso muitos não nos apreciam. Com a forma e o tamanho da noz do pinhão, amarelados, de substância e polpa interior mais mole, cheios de semente de um fulvo escuro. De suas qualidades medicinais apenas sei que as fôlhas do Araticu mais comum, maceradas em óleo de azeitona e aplicadas ao apostema, são emolientes e abstergentes do tumor. Quanto à árvore chamada Araticu pana, é semelhante às outras, delas diferindo só pelo tamanho. Pois, tem menores a flor, o fruto, tam- 
bém o tronco e as fôlhas. e cresce nas regiões palustres. As outras porém encontram-se nas florestas e em número infinito, sobretudo na vila de lguaraçu. Esta árvore, pelo tamanho e pelas fôlhas, é semelhante ao limoeiro, mas mais grossa e de um verde mais acentuado, flores grandes e de um lindo amarelo. $O$ fruto, como o do mais Araticu, é escamoso e termina em forma de cone. Dizemno tão frio que mata quem o come com freqüência, sendo por isso considerado venenoso. (Piso, 1948, p. 78-9)

Tanto a Bacoba como a Banana se consideram frutos de pouca dura e (conforme querem alguns) como figos. Uma e outra provoca flatos, refrigera moderadamente e excita o venéreo adormecido. Pouco alimentam e agradam antes ao peito que ao estômago e pretende Avicena que lhes extingue os calores (318). A Banana é um pouco mais longa, de casca amarelada e quadrangular; tirada ela, encontra-se uma polpa mole, substancial e menos suculenta que a da Bacoba; além disso, é de qualidade mais fria, nem de tão fácil digestão, senão quando muito madura. Assada é boa para os biliosos, mas não para os pituitosos. Assada quando ainda não madura é de bom emprêgo contra os fluxos do ventre. A Bacoba é mais curta, mais redonda e sem divisões angulares; mais gorda, demais disso, e de digestão mais fácil, ocupando por tal razão o primeiro lugar entre as sobremesas. Dessecada ao fogo e preparada do mesmo modo que a Banana, oferece a mesma utilidade. (Piso, 1948, p. 85)

Como se observa nos exemplos acima, inúmeras vezes os elementos que se encontram no mesmo nível de abstração dentro de uma relação genérico-específica são definidos um por oposição ao outro. Assim, as diferenças específicas são apresentadas não apenas em relação ao gênero próximo, mas também em relação aos co-hipônimos dentro de uma organização de tipo genérico-específico. 


\subsection{O percurso onomasiológico da definição}

Onomasiologia consiste no processo de busca de uma designação tomando-se como ponto de partida o plano do significado. Opõe-se, portanto, ao percurso semasiológico (da palavra à idéia). Em sua obra, Piso recorre inúmeras vezes a esse processo: primeiro descreve o referente e/ou conceito para, em seguida, indicar sua denominação. É o que se verifica nos exemplos abaixo:

Em seguida, as inúmeras fôrmas de barro, após terem recebido o suco flúido, são colocadas em ordem numas pranchas perfuradas, em casas amplíssimas (vulgarmente chamadas Casa do purgar); logo colocando-se-lhes por cima uma lama humedecida, as referidas fôrmas se purificam do mel, que antes tingia o açucar de cor escura (267). Tirado das fôrnas, é separado o [açúcar] branco do escuro, chamado Mascovado; reduzido a fragmentos, expõese ao sol sereno e seca-se bem até ser guardado em cestas. (Piso, 1948, p. 60)

A Mandihoca mole, chamada Puba, posta ao fogo para secar, denomina-se, depois de sêca, Carima. Com ela preparam os angolenses um pão de óptima qualidade, conhecido por Musa ou Angu, e algumas vezes Enfonde. (Piso, 1948, p. 62)

A Manipuera cozida encrassa a modo de papas e constitui bom alimento. Acrescentando-lhe arroz e açúcar, com água destilada de flores de laranja, assume a forma de agradabilissima conserva, chamada, com mudança de nome, Marmelada de Mandihoca. (Piso, 1948, p. 62)

Quando a árvore [cabureira] reverdece, pelos meses de fevereiro e março, fazendo-se-lhe incisões na casaca, pela lua cheia, e pendurando-se-lhe pequenos recipientes, colhe-se êste bálsamo fragrantíssimo e mui precioso chamado Cabureicica. (Piso, 1948, p. 65)

Inúmeros são, pois, os exemplos que podemos citar de definições que seguem, na obra de Piso, o percurso onomasiológico. 


\subsection{O sistema de remissivas}

No âmbito de um dicionário, o "sistema de remissivas", enquanto rede de relações léxico-semânticas, tem por objetivo garantir a recuperação e a circulação dos dados, orientando os leitores sobre o percurso a ser seguido para se obter as informações procuradas. Um sistema de remissivas que evidencie todas as relações conceptuais estabelecidas entre as entradas de um dicionário pode colocar em questão as condições práticas de execução de um projeto terminográfico. Os terminólogos são, então, obrigados a definir critérios quantitativos e qualitativos para o estabelecimento de um sistema de remissivas coerente e eficaz, adaptado à natureza e às funções específicas da obra em projeto.

A necessidade de explicitar as relações de significação no interior de um dicionário terminológico por meio do sistema de remissivas se apresenta, de acordo com certos autores, por causa da ordem alfabética das entradas. Esses sustentam que, nos vocabulários sistemáticos, a presença de um sistema de remissivas é desnecessária. Essa posição é, entretanto, contestada por outros autores como, por exemplo, Jean e Claude Dubois, que vêem nos índices alfabéticos dos vocabulários sistemáticos uma expressão do sistema de remissivas. Este último é, a nosso ver, parte integrante de todas as obras terminográficas, podendo se manifestar na macroestrutura e/ou na microestrutura, de maneira clara ou implícita, assumindo inclusive a forma de índice remissivo.

Na obra de Piso (assim como em tantas obras de diferentes tipos), encontra-se um índice remissivo após os quatro livros. Este é chamado pelo autor de Índice dos assuntos e das palavras. 


\section{N D I C E}

DOS ASSUNTOS E DAS PALAVRAS
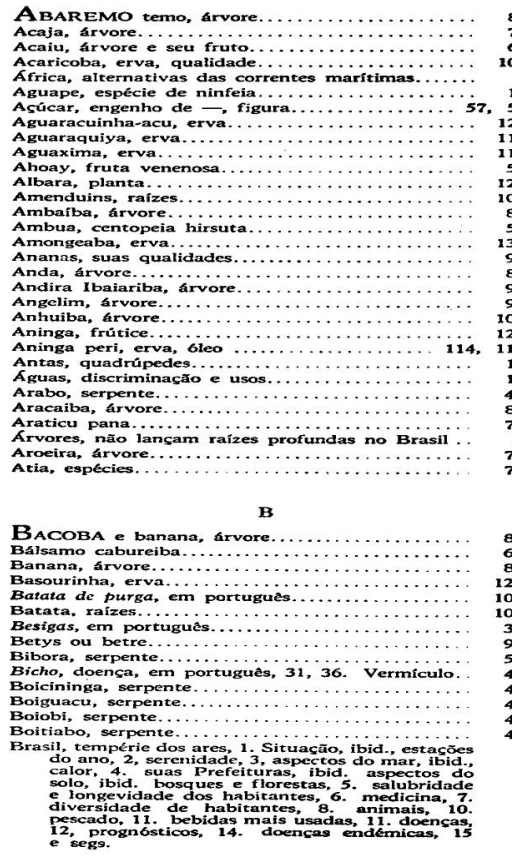

CaApia, erva, qualidade.

Caataya, erva.

Caneo, espécies.

Cananduvan, erva.

alidades.

Caapomonga, crva

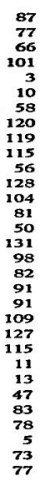

Cabureiba, arvore, 65. balsamo.

Cacaboya, serpente.

Camara juba, erva...

Cambui, murta silvestre.

Caninana, serpente.

Cana silvestre e seu uso

Cana de açcar, cultura.

Caopia, arvore.

Capiipuba. erva ...........

Caraguata,

Caranaiba, arvore.

Cascavel, serpente.

Cebipira guacu, arvo

Cerejeira brasileira.

Chabecos, doença, em portugue

Calibe, uso gabado...................

Chuvas grandes, gotas - no Bras

Chuvoso, tempo,

Cipo de cobras, em .............

Cobre de cipo, serpente...

Cobre de veado, serpente.

Cobre de corais, serpente.

Cobre vercle, serpente.

Cocoeiro, palmeira ...........

Copaiba, arvores, 65, 61

Coral branco ds Brasil

Cotora, rā.

Crapomonga segunda

Cucuraciu, serpente.

Cupouna, arvore.

Curimentos, em portuguc

Cururu-ape, erva.

Dieta dos medicos brasileiro.

Dieta dos medicos brasileiros

Doencas dos olbos

Doencas contagiosas no Brasil

Doencas, origerm no Brasil

Doencas das mulheres no Brasil

Druyploop. em holandes.

Disenteria doence.

$\mathbf{E}$

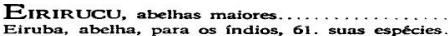

Eiruba, abelha, para os
Eixu, abelhas menores

Eixu, abelhas mence

Empige, em português

Evva d'Amor, em portugues

Erva casta ou mimos

Erva do Capitaon, em portugue

Erva do Rato, em portugues.

Erva de Nossa Senhora, em portugues

As unidades lexicais do índice remissivo da obra de Piso encontram-se organizadas em grupos seqüenciados por ordem alfabética; a primeira palavra do grupo vem sempre em letra maiúscula. Não apenas as palavras-chave são listadas nessa parte da obra, mas também outras informações que orientam o leitor a encontrar os dados que deseja em um texto que não é um dicionário e que, portanto, não trata os temas, termos e conceitos em ordem alfabética nem em ordem sistemática.

Uma rápida olhada pelos itens do índice poderia levar-nos a pensar que se trata de um índice permutado, isto é, de um "indice alfabético estabelecido de acordo com o princípio da permuta" (ISO 1087, 2000, p. 8), por permuta se compreendendo a 
"organização das unidades lexicais de modo que cada um de seus elementos constitutivos apareçam em uma dada posição. Exemplo: A unidade lexical milhões de instruções por segundo [MIPS] deveria aparecer como segue: 'instruções, milhões por segundo'e 'segundo, milhões de instruções por', a fim de garantir que os elementos constitutivos desejados apareçam nas posições apropriadas nesse caso" (ISO 1087, 2000, p. 7).

Na verdade, não se trata de um índice dessa natureza, mas sim de um índice misto entre analítico (dos assuntos tratados na obra) e remissivo (das palavras-chave contidas na obra). Este não indica todas as páginas em que as palavras-chave se encontram atualizadas, mas sim onde o tema que elas expressam é tratado. Mais ainda: em inúmeros casos especifica onde um determinado tipo de dado sobre o assunto pode ser encontrado, como nos exemplos que seguem:

CAAPIA, erva, qualidade $\rightarrow$ p. 100

MANDIHOCA, engenho, figura $\rightarrow 61$

VENENOS excogitados pelos bárbaros $\rightarrow$ p. 45

Nesses casos, o índice informa onde se localizam os dados referentes às qualidades da erva caapia, onde se pode ver uma ilustração do engenho da mandioca ou onde as informações sobre os venenos conhecidos e manipulados pelos indigenas e africanos que vivem no Brasil podem ser lidas.

$\mathrm{O}$ aqui analisado faz, em suma, jus ao título que carrega Índice dos assuntos e das palavras -, sendo talvez mais de assuntos do que de palavras. Tal como todos os índices alfabéticos, esse também é expressão de um sistema de remissivas subjacente à obra, embora não se trate de um dicionário.

\section{Conclusão}

A obra de autoria do médico holandês Guilherme Piso, publicada em 1648, constitui o resultado da primeira missão científica propriamente dita ao Brasil e seu discurso é o do cientista moderno (da época), que procura analisar o objeto em si, 
descobrir-lhe as propriedades e funcionamento, que procura aplicar os conhecimentos adquiridos, desenvolvendo novos remédios e terapêuticas. Inaugura, portanto, no Brasil, uma linha de observação até então não empregada nos relatos e descrições do país. À Medicina européia abriu as portas de um novo universo - o da Medicina dos indígenas brasileiros e das propriedades medicinais de plantas antes desconhecidas -, tendo, portanto, contribuído para dinamizar a Ciência da época. De medicina brasiliensi é considerada uma obra prima, fundadora da Medicina Tropical no mundo.

O objetivo deste artigo ao analisar essa obra foi o de mostrar que o discurso lexicográfico pode estar presente em documentos científicos que não se caracterizam como dicionários. No trabalho de Piso, a presença do discurso lexicográfico se evidencia por um processo de elucidação do léxico especializado empregado pelo autor, notadamente no que concerne a termos que designam doenças endêmicas do Brasil e espécies da flora e da fauna brasileira. Também se realiza pela utilização de recursos gráficos que são típicos de obras lexicográficas.

Evidenciamos a existência de verdadeiros enunciados definicionais e/ou enciclopédicos, muitos deles semelhantes ao modelo proposto pela Terminologia como sendo ideal para a distribuição da carga sêmica nas definições terminológicas: gênero próximo + diferenças específicas. Assim, no que concerne às definições de gêneros e espécies dos animais e plantas brasileiras, os elementos são tratados por Piso como uma relação hierárquica: o elemento mais genérico (ou superordenado) funciona como uma macro-classe de equivalência, contendo, numa relação de inclusão, os específicos; ambos mantêm entre si uma relação hiperonímica-hiponímica. No caso dos termos que pertencem ao mesmo nivel de abstração dentro desse sistema estruturado (os co-hipônimos), as definições dadas pelo autor, além de retomarem o gênero próximo, também procuram descrevêlos por oposição a seus co-hipônimos.

O percurso onomasiológico é freqüente na obra de Piso enquanto processo de elaboração de definições. Esse percurso marcou a Terminologia desde sua criação em 1935, notadamente sob a égide da Teoria Geral da Terminologia, tendo caracteriza- 
do o trabalho terminológico durante anos. Nesse sentido, vemos na obra de Piso mais uma semelhança com os preceitos da Terminologia.

Atribuímos a existência desse discurso lexicográfico/terminográfico a diversas razões: a) essa era uma característica geral de textos da época da colonização do Brasil, que procuravam explicar ao leitor europeu as coisas próprias de um mundo por eles desconhecidas; b) a preocupação em descrever o léxico e a língua foi uma marca dos estudos naturalistas ao longo dos períodos colonial e imperial brasileiros; c) alguns aspectos dicionarísticos encontrados na obra de Piso também podem ser encontrados em qualquer Tratado científico, de épocas diferentes, inclusive da atualidade, sendo, portanto, uma característica geral desse tipo de obra; d) outros aspectos são, enfim, particulares do trabalho desse autor, sobretudo no que concerne à forma como o discurso lexicográfico ganha expressão na obra.

Acreditamos que o discurso lexicográfico, ou melhor, terminográfico, encontrado nos livros de Piso dê-se também em outros documentos científicos pertencentes a épocas diferentes. Estamos convencidos disso e temos a intenção de demonstrar nossa hipótese em outros trabalhos, procedendo a novas pesquisas.

\section{Referências bibliográficas}

BARROS, Lidia Almeida.(2004) Curso Básico de Terminologia. São Paulo: EDUSP.

FELBER, Helmut. (1984) Manuel de terminologie. Paris, UNESCO/ INFOTERM.

NUNES, José Horta. (1996) Discurso e instrumentos lingüísticos no Brasil: dos relatos de viajantes aos primeiros dicionários. Tese defendida na Universidade Estadual de Campinas-UNICAMP.

. (2002) Dicionarização no Brasil: condições e processo. In: NUNES, José Horta, PETTER, Margarida. História do saber lexical e constituição de um léxico brasileiro. São Paulo: Humanitas/Pontes, p. 99122.

ORGANISATION INTERNATIONALE DE NORMALISATION. (1990) Terminologie - Vocabulaire. Genebra. ISO, (Norme Internationale ISO 1087, 1990). 
ORGANISATION INTERNATIONALE DE NORMALISATION. (2000) Norme 1087. Travaux terminologiques - Vocabulaire. Partie 2: Applications logicielles. Genebra: ISSO.

PISO, Guilherme, MARCGRAV, Georg. (1948) Historia naturalis brasiliae. São Paulo: Imprensa Oficial do Estado de São Paulo.

PISO, Guilherme. (1948) De medicina brasiliensi. São Paulo: Imprensa Oficial do Estado de São Paulo, 4 vol.

SÃO PAULO, Fernando. (1948) Comentários sobre os dois primeiros livros de Piso. PISO, Guilherme, MARCGRAV, Georg. (1948) Historia naturalis brasiliae. São Paulo: Imprensa Oficial do Estado de São Paulo, p. 331-398.

TAUNAY, Affonso de E. (1948) Escorço biográfico. PISO, Guilherme, MARCGRAV, Georg. (1948) Historia naturalis brasiliae. São Paulo: Imprensa Oficial do Estado de São Paulo, p. 153-230.

VERDELHO, Telmo. (2002) Dicionários portugueses, breve história. In: NUNES, J. H., PETTER, Margarida. História do saber lexical e constituição de um léxico brasileiro. São Paulo: Humanitas/Pontes, p. 15-64. 